\title{
Economics
}

The Open-Access, Open-Assessment E-Journal

Vol. 13, 2019-45 | October 29, 2019 | http://dx.doi.org/10.5018/economics-ejournal.ja.2019-45

\section{Dividend payout ratio follows a Tweedie distribution: international evidence}

\author{
Victor Dragotă, Daniel Traian Pele, and Hanaan Yaseen
}

\begin{abstract}
Dividend policy is still a largely discussed issue in corporate finance literature. One of the main indicators used in analysing the dividend policy is the dividend payout ratio. Using a database consisting of 12,085 companies operating in 73 countries, for the period 20082014, the authors found that the dividend payout ratio follows a Tweedie distribution, and not a normal one. This distribution is stable over time for the entire analysed period. In addition, it describes the case of almost all the countries included in the sample. Thus, a better estimation of the probability that dividend payout ratio is lower or higher than a benchmark can be provided. Also, an analysis of dividend policy, distinctly considering payer versus non-payer companies, can offer additional important information for both practitioners and academics.
\end{abstract}

JEL G35 C01 C51 C55

Keywords Dividend policy; dividend payout ratio; Tweedie distribution

Authors

Victor Dragotă, Bucharest University of Economic Studies, Romania, victor.dragota@fin.ase.ro

Daniel Traian Pele, Bucharest University of Economic Studies, Romania

Hanaan Yaseen, Bucharest University of Economic Studies, Romania

Citation Victor Dragotă, Daniel Traian Pele, and Hanaan Yaseen (2019). Dividend payout ratio follows a Tweedie distribution: international evidence. Economics:

The Open-Access, Open-Assessment E-Journal, 13 (2019-45): 1-34.

http://dx.doi.org/10.5018/economics-ejournal.ja.2019-45 


\section{Introduction}

Corporate finance literature discusses dividend policy from different perspectives (Lintner 1956, Miller and Modigliani 1961, Bhattacharya 1979, Easterbrook 1984, Holder et al. 1998, La Porta et al. 2000, Fama and French 2001, Fidrmuc and Jacob, 2010, Floyd et al, 2015, Jiang et al. 2017 , etc.). Different viewpoints on dividend policy are contradictory, from its neutral impact on firms' value (Miller and Modigliani 1961) to normative advices to increase (Graham and Dodd 1951) or to decrease (Walter 1956) the amount paid to shareholders, or to explain this financial decision through agency problems, asymmetrical information, socio-cultural or institutional factors, etc. (Bhattacharya 1979, Easterbrook 1984, La Porta et al. 2000, Fidrmuc and Jacob 2010, etc.). Among them, the studies concerning the factors determining dividend policy are an important direction (see, among others, La Porta et al. 2000, Fidrmuc and Jacob 2010, Nicolosi 2013, Ye et al. 2019).

Different indicators are used for modelling dividend policy, each of them with its informative power. One of the most important is the dividend payout ratio (Holder et al. 1998, La Porta et al. 2000, Ye et al. 2019) (hereafter, DPR), respectively the part of the net earnings paid to shareholders, as dividends, considering the firms which record net profits (and excluding those which record losses). ${ }^{1}$ In a sense, DPR reflects exactly the interest expressed by one profitable company for paying dividends to its shareholders. Analysed for one period, a DPR equal to $100 \%$ reflects a totally dedicated policy to pay dividends to shareholders, and one of $0 \%$ a reflection of a non-interest to dividends (argued in many cases as the company's interest for investing). DPR is used in a large variety of studies, as dependent variable (e.g., Holder et al. 1998, La Porta et al. 2000, Faccio et al. 2001, Fidrmuc and Jacob 2010, Jiang et al. 2017, etc.), but also as explanatory variable in different contexts (e.g., Lintner 1956, Lamont 1998, Lettau and Ludvigson 2001, Arnott and Asness 2003, Cincotti et al. 2010, Baker et al. 2012, He et al. 2017). In such studies, the average DPR is often considered representative, as in the case of a Gaussian distribution.

Many papers analyse the determining factors of DPR using a classical regression (e.g., La Porta et al. 2000, Fidrmuc and Jacob 2010, Jiang et al 2017). Other papers analyse the propensity to pay dividends ${ }^{2}$ and its determinants (e.g., Denis and Osobov 2008, von Eije and Megginson 2008, Fatemi and Bildik 2012, Kuo et al. 2013, Banyi and Kahle 2014, Jiang et al 2017). One missing link between considering the averages DPR and the propensity to pay dividends in modelling dividend policy can be somehow intuited. DPR does not follow a normal distribution. Figure 1 depicts DPR distribution for a number of 12,085 companies from 73 countries, in the period 2008-2014. In this study, we show that this empirical distribution may

\footnotetext{
${ }^{1}$ DPR can be also calculated as ratio between dividend per share and earnings per share. This second expression is the most familiar for investors on capital market. At a macroeconomic level, Ferris et al. (2009) use in their analysis an aggregate DPR, respectively a ratio between the value of total dividends and the total earnings for a country.

2 Denis and Osobov (2008) define the propensity to pay dividends, respectively the characteristic of one company to be a dividend payer or not. If $\mathrm{DPR}=0$, the company is a dividend payer. If $\mathrm{DPR}>0$, the company is not a dividend payer.
} 


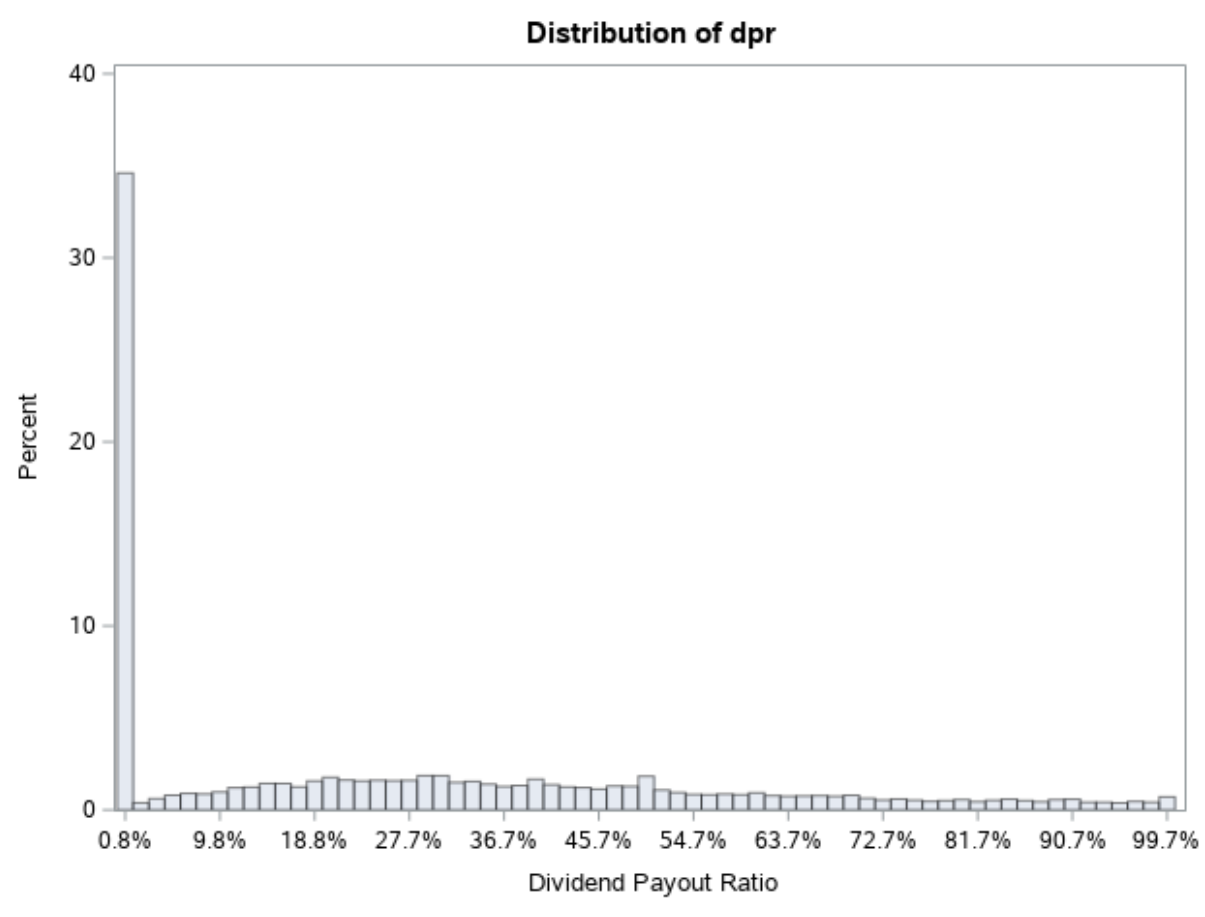

Figure 1: Dividend payout ratio for the companies included in the sample, in the period 2008-2014. All companies' financials were collected from the Thomson Research Worldscope database. DPR is computed as: $D P R=\frac{\text { Dividends }}{\text { Net income }}$.

be fitted at best by a Tweedie distribution (Tweedie 1984). Moreover, this distribution is stable in time for the entire analysed period. In addition, it describes the case of almost all the countries included in the sample and the most part of the years (some more detailed statistics are provided in Appendix 1). As far as we know, finding the distribution for DPR is a new contribution for financial literature.

The distribution depicted in Figure 1 suggests that dividend policy is mainly an issue of "to be or not to be" a dividend payer, some authors suggesting the decrease in dividend payments in time (Fama and French 2001, Fatemi and Bildik 2012, Kuo et al. 2013), which can be modelled through the propensity to pay dividends (Fama and French 2001, Denis and Osobov 2008, von Eije and Megginson 2008, Fatemi and Bildik 2012, Kuo et al. 2013, Banyi and Kahle 2014, Floyd et al. 2015, Jiang et al. 2017, etc.). As practical implication, a proper analysis of DPR should consider both components of the distribution - the 0 inflated component and the distribution for DPR $>0$. However, as Figure 1 suggests, this is not a $0 \% / 100 \%$ dividend payout ratio policy! An analysis concerned only about the decision to pay or not to pay dividend can miss some important information.

The most appropriate distribution for modelling DPR is not the normal (Gaussian) one, but the less used Tweedie distribution, proposed by Maurice Tweedie (1984). Using a better fit for the distribution, a better estimation of the probability that the event to occur (e.g., DPR to be lower or higher than a benchmark) can be provided. This result can be useful for instance in the context of international portfolio management, especially if the investments are made in a large 
number of companies (with minority participations), and when forecasting of the future collected dividends is of interest.

One important contribution, comparative to previous research, is the large number of countries considered (73). For instance, the database used by La Porta et al. (2000) includes 33 countries, the one of Ferris et al. (2009) 25, etc. Our sample is geographically diverse, including countries from Africa, North and South Americas, Asia, Australia, and Europe. From here, a large diversity regarding the cultural values, but also legal systems (our sample includes common law, but also civil law countries) can be noticed.

The remainder of our paper is structured as follows. Some related studies are discussed in Section 2. Section 3 presents the methodology. Section 4 describes the data. Section 5 presents and examines the results. In Section 6, we conclude.

\section{Theoretical background. Modelling dividend policy through dividend payout ratio}

Different indicators are used for modelling dividend policy, in various contexts (see Table 1). Of course, each of these indicators expresses something else, but all of them can be used in analysing dividend policy. Two indicators are extensively used in studies on dividend policy, respectively dividend payout ratio (DPR) and the propensity to pay dividends (hereafter, PPD). They are somehow related, in the sense that PPD can be modelled as a particular case of DPR. Thus, $\mathrm{PPD}$ can be defined as: $\mathrm{PPD}=\mathrm{DPR}$ if $\mathrm{DPR}=0$, and $\mathrm{PPD}=1$ if $\mathrm{DPR}>0$.

DPR is defined as the ratio between net dividend paid to shareholders and net earnings (for instance, DPR in the year $t$, as a ratio between dividend per share and earnings per share, both recorded in the year $t$ ) and calculated only if the company records profit, and not loss (La Porta et al. 2000, Fidrmuc and Jacob 2010). Dividend is considered usually as total cash dividend paid to common and preferred shareholders (La Porta et al. 2000, Fidrmuc and Jacob 2010). ${ }^{3}$ DPR can be considered as explaining the interest of the shareholders for receiving dividends (or, in some cases, the interest of managers to protect the shareholders' interests). Share repurchases can be considered as an alternative to dividend payments (La Porta et al. 2000, von Eije and Megginson 2008, Fidrmuc and Jacob 2010, Banyi and Kahle 2014, Baker and Weigand 2015), and some studies correct DPR for accounting for this type of shareholders' remuneration (e.g., Renneboog and Trojanowski 2007, Floyd et al 2015, Ye et al. 2019). However, share repurchases imply the termination of the role as shareholder for the receiver of the payment, and this is why it should be analyzed independently by dividend payments.

Undoubtedly, as most of the financial indicators, DPR has certain limits. Net earnings depend on the countries' accounting conventions and are not always comparable from one country to another, being also easily manipulated by "accounting tricks". Also, "diversion of

\footnotetext{
3 In some cases, supplementary adjustments are made. For instance, "Earnings are measured after taxes and interest but before extraordinary items" (e.g., La Porta et al. 2000, Faccio et al. 2001).
} 
Table 1: Indicators used in modelling dividend policy

\begin{tabular}{|c|c|}
\hline Indicator & Studies \\
\hline $\begin{array}{l}\text { Dividend payout ratio (dividend-to- } \\
\text { earnings ratio) }\end{array}$ & $\begin{array}{l}\text { Lintner (1956), Holder et al. (1998), La Porta et al. (2000), Faccio et al. } \\
\text { (2001), Aivazian et al. (2003), Renneboog and Trojanowski (2007), } \\
\text { Fidrmuc and Jacob (2010), Fatemi and Bildik (2012), Floyd et al. (2015), } \\
\text { He et al. (2017), Jiang et al. (2017), Chen et al. (2017), Yaseen and Dragotă } \\
\text { (2019), Ye et al. (2019), Yaseen (2019) }\end{array}$ \\
\hline $\begin{array}{l}\text { Propensity to pay dividends (dummy } \\
\text { variable, reflecting the quality of dividend } \\
\text { payer / non-payer) }\end{array}$ & $\begin{array}{l}\text { Fama and French (2001), Denis and Osobov (2008), von Eije and } \\
\text { Megginson (2008), Bena and Hanousek (2008), Ferris et al. (2009), Fatemi } \\
\text { and Bildik (2012), Kuo et al. (2013), Banyi and Kahle (2014), Zheng and } \\
\text { Ashraf (2014), Floyd et al. (2015), He et al. (2017), Jiang et al. (2017), } \\
\text { Yaseen and Dragotă (2019), Ye et al. (2019) }\end{array}$ \\
\hline Dividends / sales & $\begin{array}{l}\text { La Porta et al. (2000), Faccio et al. (2001), Shao et al. (2010), Fidrmuc and } \\
\text { Jacob (2010), Chen et al. (2017) }\end{array}$ \\
\hline Dividends / cash flow & $\begin{array}{l}\text { La Porta et al. (2000), Faccio et al. (2001), Fidrmuc and Jacob (2010), Jiang } \\
\text { et al. (2017) }\end{array}$ \\
\hline $\begin{array}{l}\text { Dividend / earnings before interest and } \\
\text { taxes }\end{array}$ & Renneboog and Trojanowski (2007) \\
\hline $\begin{array}{l}\text { Dividends / market capitalization } \\
\text { (Dividend yield) }\end{array}$ & $\begin{array}{l}\text { Faccio et al. (2001), Aivazian et al. (2003), Nicolosi (2013), Arnott and } \\
\text { Asness (2003), Desai and Jin (2011), Nicolosi (2013), He et al. (2017), } \\
\text { Yaseen (2019) }\end{array}$ \\
\hline Dividends / total assets & $\begin{array}{l}\text { Shao et al. (2010), Zheng and Ashraf (2014), Chen et al. (2017), Ye et al. } \\
\text { (2019) }\end{array}$ \\
\hline Dividend / equity & Yaseen (2019) \\
\hline Dividend initiation & $\begin{array}{l}\text { DeAngelo and DeAngelo (1990), Ferris et al. (2009), Huang et al. (2015), } \\
\text { Chen et al. (2017), He et al. (2017) }\end{array}$ \\
\hline Dividend omission & DeAngelo and DeAngelo (1990), Huang et al. (2015), He et al. (2017) \\
\hline Dividend re-initiation & Chen et al. (2017) \\
\hline Dividend per share & Bena and Hanousek (2008), Chen et al. (2017) \\
\hline $\begin{array}{l}\text { Dividend payments (total amount paid as } \\
\text { dividend) }\end{array}$ & Lintner (1956), Renneboog and Trojanowski (2007) \\
\hline
\end{tabular}

resources may occur before earnings are reported" (in this case, dividend payout ratio "overestimates the share of true earnings that is paid as dividends" (La Porta et al. 2000). ${ }^{4}$ It can be stated that DPR is also a classical, traditional indicator. It expresses the share of profit paid to shareholders. In this vision, profit is somehow considered having "a cash flow essence". As signalling theory notices (Bhattacharya 1979, Kalay 1980), in practice, one company can record profits, but having not enough cash for paying dividends. Also, if one company pays dividends from previous years earnings (from reserves), DPR can be higher than $100 \%$. This nonsynchronicity between dividends (an amount paid from the cash existent in one financial exercise) and net earnings (the result in previous year) can complicate also the financial interpretation of DPR.

\footnotetext{
4 These problems are solved somehow using dividend-to-sales or dividend-to-cash flow ratios (La Porta et al. 2000, Faccio et al. 2001, Fidrmuc and Jacob 2010, etc.). However, these indicators do not reflect a portion from net earnings paid as dividend, dividends being defined as a part of the earnings distributed to shareholders.
} 
DPR does not reflect a return (like dividend yield); it is a share of profit paid to shareholders. If dividends and retained earnings are considered as expressing opposite interests (see the literature regarding minority shareholders' protection, e.g., La Porta et al. 2000), DPR would reflect a higher interest for one issue or another or, maybe, a power in negotiation. However, the interpretation of the indicator should be made cautiously. If one company records 100 monetary units (m.u.) as earnings and pays 50 m.u. as dividends, it records only a $50 \%$ DPR, comparatively with another, which pays $100 \%$ as dividends from its 1 m.u. earnings. Looking only to DPR, the second one seems to be more oriented to shareholders; however, it does not mean that its shareholders would be more satisfied.

DPR is used as dependent variable in regressions (La Porta et al. 2000, Fidrmuc and Jacob 2010, Jiang et al 2017). Different factors are considered as determinants of DPR, some of them - financial (e.g., size, return of assets, leverage, sales growth, in Fidrmuc and Jacob 2010, Jiang et al 2017, Ye et al. 2019), other - legal (legal system, mandatory dividends, tax advantages, etc., as in La Porta et al. 2000, Fidrmuc and Jacob 2010, Ye et al. 2019, etc.), cultural (individualism, power distance, uncertainty avoidance, 5 in Fidrmuc and Jacob 2010), related to ownership structure (Jiang et al 2017, Ye et al. 2019), board gender diversity (Chen et al. 2017, Ye et al. 2019), etc. DPR is also used as independent variable in some studies (e.g., Lintner 1956, Lamont 1998, Lettau and Ludvigson 2001, Arnott and Asness 2003, Cincotti et al 2010, Baker et al. 2012, He et al. 2017, Chen and Desiderio 2018).

Based on empirical evidences, different papers found that the presence of non-paying dividends companies is significant (Fama and French 2001, von Eije and Megginson 2008, Fatemi and Bildik 2012, Kuo et al. 2013). Maybe for this reason, many papers prefer to analyse the propensity to pay dividends and its determinants, along with dividend payout ratio or not (e.g., Denis and Osobov 2008, von Eije and Megginson 2008, Fatemi and Bildik 2012, Kuo et al. 2013, Banyi and Kahle 2014, Jiang et al. 2017, Ye et al. 2019) (see also Table 1). Even PPD is a less sensitive indicator, it has the same purpose as DPR in reflecting the company's interest for paying dividends for shareholders.

One missing link between considering averages DPR and propensity to pay dividends in modelling dividend policy can be somehow intuited. On the one hand, the use of the average DPR can be misleading, as long as DPR is $0 \%$ in many cases. An average DPR should be interpreted cautiously; it is as if you would say that in average you feel all right if one part of you is kept in frozen water and the other one in boiling water. On the other hand, neglecting the distribution of DPR in the absence of DPR $=0$ (considering $1 \%$ DPR to be as such important as a $100 \%$ DPR) can determine missing some information.

For all these reasons, finding if probability distribution of DPR can be modelled can provide a useful result for both academics and practitioners. Finding the probability distribution for one variable is studied in literature (e.g., Clauset et al. 2009). In general, in is accepted that the selection procedure is following some subsequent steps, respectively (Clauset et al. 2009): (1) choose a suitable theoretical model; (2) estimate the model parameters; (3) determine the significance level and use a goodness-of-fit test in order to determine the most appropriate theoretical distribution. As far as we know, finding the distribution for DPR is a new contribution for financial literature.

\footnotetext{
5 These indicators are proposed by Hofstede (2001), as proxies for the national culture.
} 


\section{$3 \quad$ Methodology}

Our methodology is focused on finding the most appropriate distribution for DPR. In order to fit the probability distribution for DPR, we follow the methodology recommended by Clauset et al. (2009), and we applied it for the analysed variable. Thus, the fitting problem can be split in three main tasks (Clauset et al. 2009).

First, we have chosen a suitable theoretical model. Descriptive statistics like histogram and skewness are useful in this step. Based on the shape of the empirical distribution, we have decided to estimate a range of theoretical distribution that may fit the data: Tweedie, Scaled Tweedie, Lognormal, Burr, Weibull, Inverse Gaussian, Exponential, Generalized Pareto Distribution, Pareto and Gamma distribution. The Tweedie distribution, as a model for zero-inflated data (see Gilchrist and Drinkwater, 1999), has been previously used in other areas, such as healthcare data (Kurz 2017), modelling insurance claims (Renshaw 1994; Jørgensen et al. 1994), etc.

Secondly, we have estimated the model parameters. In order to estimate the parameters of the theoretical distributions, the Maximum Likelihood method was used.

Finally, we have determined the significance level and we have used a goodness-of-fit test in order to determine the most appropriate theoretical distribution. For finding the most appropriate distribution for the data, we have used the Anderson-Darling test (Anderson and Darling 1954). This is one alternative used to test and to find the distribution of experimental data that follows a theoretical distribution. The conclusion of the Anderson-Darling test is usually drawn by comparing the obtained statistics with the available critical value. This test is one of the most frequent tests used to find the best distribution for the data, generally called „goodness-of-fit tests” (Pearson 1895, Anderson and Darling 1954, Stephens 1974, Jäntschi and Bolboacă 2018). This methodology has the advantage of allowing a more sensitive test (Scholz and Stephens 1987). By minimizing the statistics obtained from the Anderson Darling test, we have chosen the most appropriate distribution for our data.

\section{$4 \quad$ Data}

All companies' financials were collected from the Thomson Research Worldscope database. ${ }^{6}$ We have included in our database only those countries with minimum 10 companies available for the entire period (for this reason, we have excluded from the initial database some countries). In addition, we have not considered the financial institutions because of the difference in the accounting standards for financial reporting, as La Porta et al. (2000), Fidrmuc and Jacob (2010), Jiang et al. (2017), etc. 7, 8 Furthermore, we have imported from the original database only companies with data available for the entire analysed period. Also, we have

\footnotetext{
6 The access to the Thomson Research Worldscope Database was granted by Deloitte Romania.

7 Different studies, after the exclusion of companies with missing values, eliminate from their databases: (i) utility companies (Fidrmuc and Jacob, 2010); (ii) companies from Luxembourg (La Porta et al. 2000, Fidrmuc and Jacob 2010); (iii) companies completely or partially owned by the governments (La Porta et al. 2000); (iv) companies from
} 
excluded from our database those companies which recorded negative net income (as in La Porta et al. 2000, Fidrmuc and Jacob 2010). The inclusion of this kind of data is incoherent with the financial logic of the indicator - dividend payout ratio is defined as a share of profit paid to shareholders. Another criterion for the imported data from Thomson Research Worldscope was that dividend DPR $\geq 0$ (to eliminate possible negative dividend payout ratio) (Jiang et al. 2017). We considered dividends, but not other forms of shareholders' remuneration (such as shares repurchases) (as Floyd et al. 2015, among others) (due to data availability, but also because share repurchases determine the end of the quality of company's shareholder for their receiver). Also, have considered only cash dividends, and no other "cosmetically" (non-cash) operations (e.g., dividends in stocks).

The final database consists of 12,085 companies operating in 73 countries in the period 2008-2014. As such, our database covers a crisis, but also a post-crisis period. The data are winsorized to $2 \%$ and DPR is limited to $100 \% .{ }^{9}$ We have considered each company as being a different and sole company, in the case of a group of companies, which activates in more than one country. ${ }^{10}$

Appendix 2 presents the descriptive statistics for DPR for the analysed countries. The number of companies per country is constant for the entire period analysed and the average number of companies per country is 168 . Table 2 provides much more details about the process of building the final sample.

Table 2: Final sample construction

\begin{tabular}{ll}
\hline Description & Companies \\
\hline Total number of companies imported from the database & 14,071 \\
Banks and investment trust & 1,540 \\
Companies without a specific industry (not mentioned in the database) & 30 \\
National Banks & 2 \\
Negative Assets, Negative Sales, Negative Income or other aberrant financial data & 336 \\
Companies from countries with less than 10 companies & 78 \\
\hline Final Sample & $\mathbf{1 2 , 0 8 5}$ \\
\hline
\end{tabular}

socialist or former socialist countries (La Porta et al. 2000). We included these categories for assuring a larger perspective on DPR. As observation, in our database, inclusion of Luxembourg does not have an important impact, as long it counts only with 56 records. In addition, even some particularities persist for the economies of socialist or former socialist countries, we do not consider them significant for the purpose of our study.

8 Zheng and Ashraf (2014) analyze the banks' dividend policy in an international context.

${ }^{9}$ In some cases, the rough data is questionable per se. In this category can be mentioned companies with negative dividends (reported also in Fidrmuc and Jacob 2010), or with dividends exceeding sales (reported in La Porta et al. 2000, Fidrmuc and Jacob 2010). The quality of the databases used can be a problem. For instance, Fidrmuc and Jacob (2010) use as main source of data "Standard \& Poor's Capital IQ database, which provides data covering company information for 58,670 public companies". From this total number of companies, the authors exclude 37,109 companies (that means approximately $63.25 \%$ !!!), because they have missing dividend data, negative dividends or dividends exceeding sales. DPR can be greater than $100 \%$ if dividends are paid from reserves. We did not consider this case for the reasons explained in Section 2.

10 Relatively the same database was used in Yaseen and Dragotă (2019) and Yaseen (2019). 
Appendix 1 presents DPR distributions for the countries included in our sample, for the period 2008-2014. In almost all of the cases (53 countries from 73, respectively $72.6 \%$ from the total population), DPR distribution is zero inflated (the modal value of the distribution equals $0) .{ }^{11}$

One issue that can complicate the picture is the existence in some countries of the mandatory dividend, respectively a legal requirement that a fraction of earnings to be paid as dividend. ${ }^{12}$ The results (somehow surprising) confirm the same distribution even for the cases of the countries with regulated dividend payment. The mode for DPR for Brazil, Greece, Peru, Philippines and Venezuela is zero, and the percent of companies that do not pay dividends in Chile is important (44\%). ${ }^{13}$

Table 3 provides the descriptive statistics for DPR. As observation, a look only to the mean (and to the median) of the population can be misleading. The mode is $0 \%$ and a closer look to the distribution of the variable confirms that, for the entire population, but also for the majority of the countries, the distribution of DPR is a zero-inflated distribution - the mode being 0 , with the corresponding probability significantly higher than the other probabilities. This phenomenon is documented also by many other studies (Fama and French 2001, Denis and Osobov 2008, von Eije and Megginson 2008, Fatemi and Bildik 2012, Kuo et al. 2013).

Table 3: Descriptive Statistics for Dividend Payout Ratio

\begin{tabular}{llll}
\hline Number of records & 71,824 & Interquartile Range & $47.06 \%$ \\
Mean & $27.734 \%$ & Variance & 0.081 \\
Standard Deviation & $28.383 \%$ & Excess Kurtosis & -0.462 \\
Skewness & 0.767 & Standard Error Mean & 0.001 \\
Coefficient of Variation & 102.338 & Median & $21.840 \%$ \\
& & Mode & $0.00 \%$ \\
\hline
\end{tabular}

\footnotetext{
11 The case of Oman is somehow between DPR zero-inflated distribution and the other case (see Appendix 1), but the same pattern as in the general case can be suspected, too.

12 La Porta et al. (2000) mention as countries with a mandatory dividend Brazil, Chile, Colombia, Greece, Venezuela and, in some extent, Germany. La Porta et al. (2000) exclude these countries from their analysis from the beginning. However, they mention that "they nevertheless appear, in the data, to have lower payouts than required by the law. A possible reason for this is that the accounting earnings reported to the authorities for the purpose of compliance with mandatory dividend rules are lower than the earnings reported to the shareholders which we use in our analysis". La Porta et al. (2000) use the March 1996 edition of the WorldScope Database, "which presents information on the (typically) largest firms in 46 countries". According to Fidrmuc and Jacob (2010), such requirements are present in Brazil, Chile, Greece, Peru, and the Philippines. Huang et al. (2015) mention in this category Brazil, Chile, Colombia, Greece, and Venezuela. The differences can be related not only to the countries included in the database, but also to the moment of analysis.

13 Colombia is not included in our database.
} 


\section{$5 \quad$ Results}

Analysing visually the histogram of distribution, it can be easily observed that it is a zeroinflated distribution (see also Appendix 3). Statistical literature documents the existence of different zero-inflated distributions (e.g., Poisson, Gamma, Tweedie) (El-Shaarawi et al. 2011, Jørgensen and Kokonendji 2016, Bonat and Kokonendji 2017).

By minimizing the statistics obtained from the Anderson Darling test, we have chosen the Tweedie Distribution as being the most appropriate distribution for our data (see Table 4). Figure 2 explains graphically this choice. Figure 2 depicts the empirical distribution function of DPR versus the estimated Tweedie Cumulative Distribution Function. It can be observed that the estimated Tweedie distribution fits the best the empirical distribution of DPR, out the selected probability density functions. Figure 3 fits the empirical distribution with the Tweedie distribution. Figure 4 shows the conditional probability density function estimates for Tweedie distribution against the empirical distribution: Tweedie distribution is a good choice in approximating the real distribution.

Tweedie distribution (Tweedie 1984) is included in the class of exponential dispersion models. Some familiar distributions are special cases of the Tweedie distribution (e.g., normal, Poisson, compound Poisson gamma distribution, etc.) (Kurz 2017). They have positive mass at zero, but are otherwise continuous. Tweedie distribution is a special case of exponential dispersion models, a class of models used to describe error distributions for the generalized linear model.

If $\mathrm{Y}$ is a Tweedie random variable, then the mean and the variance are $E(Y)=\mu$ and $\operatorname{Var}(Y)=\phi \mu^{p}$, where $\phi$ is the dispersion parameter and $p$ is an extra parameter that controls the variance of the distribution. The Tweedie distribution is not defined when $p$ is between 0 and 1 . In practice, the most interesting range is from 1 to 2 , in which the Tweedie distribution gradually loses its mass at 0 as it shifts from a Poisson distribution to a gamma distribution. For $p>1$, the Tweedie probability density function (pdf) has the following form:

$f(x ; \mu, \phi, p)=a(x, \phi) \exp \left[\frac{1}{\phi}\left(\frac{x \mu^{1-p}}{1-p}-k(\mu, p)\right)\right]$

Table 4: Model Selection based on the Anderson-Darling test

\begin{tabular}{lccc}
\hline Distribution & Converged & Anderson-Darling Statistic & Selected \\
\hline Tweedie & Yes & -52014 & Yes \\
Scaled Tweedie & Yes & -52011 & No \\
Lognormal & Yes & -48101 & No \\
Burr & No & -47679 & No \\
Weibull & Yes & -47519 & No \\
Inverse Gaussian & Yes & -45203 & No \\
Exponential & Yes & -41865 & No \\
Generalized Pareto Distribution & Yes & -41856 & No \\
Pareto & Yes & -41710 & No \\
Gamma & Yes & -35549 & No \\
\hline
\end{tabular}


Figure 2: Estimates of Empirical Distribution Function of Dividend Payout Ratio (EDF) and other distributions

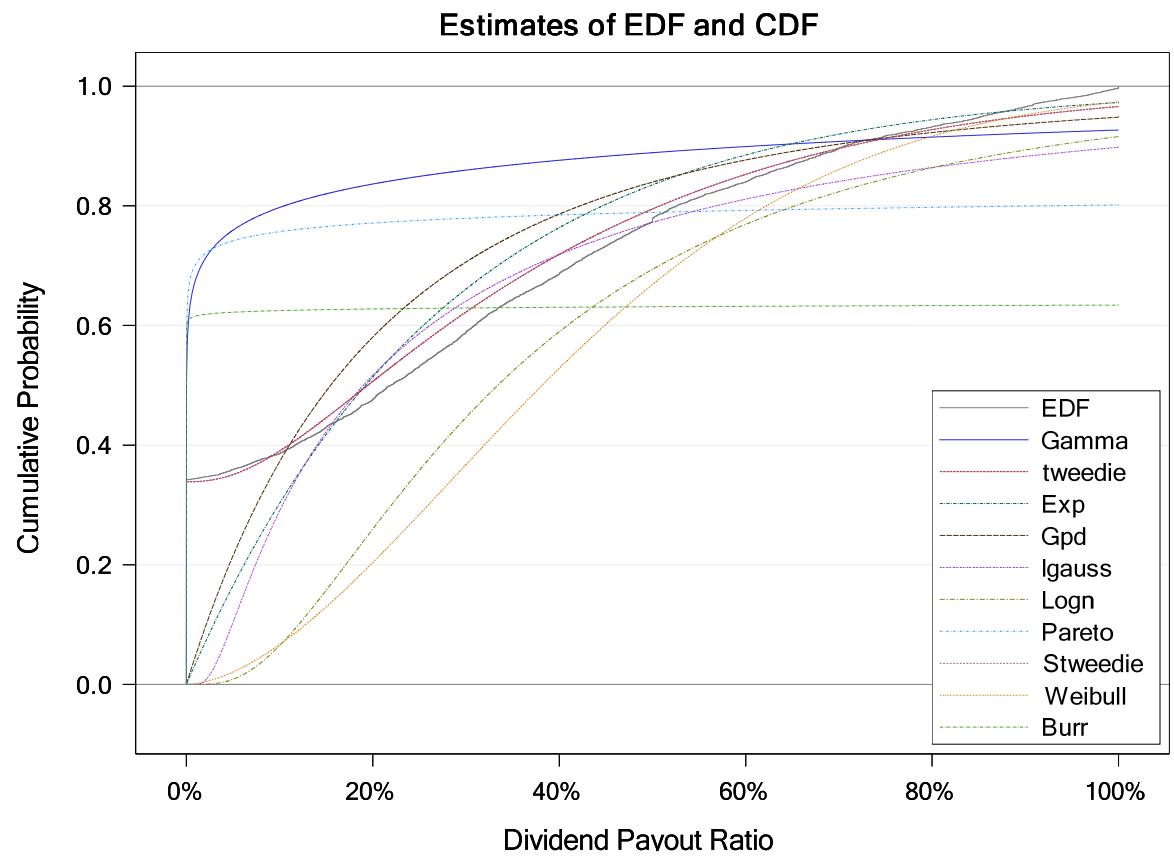

Figure 3: Empirical Distribution Function of Dividend Payout Ratio (EDF) versus the estimated Tweedie Cumulative Distribution Function

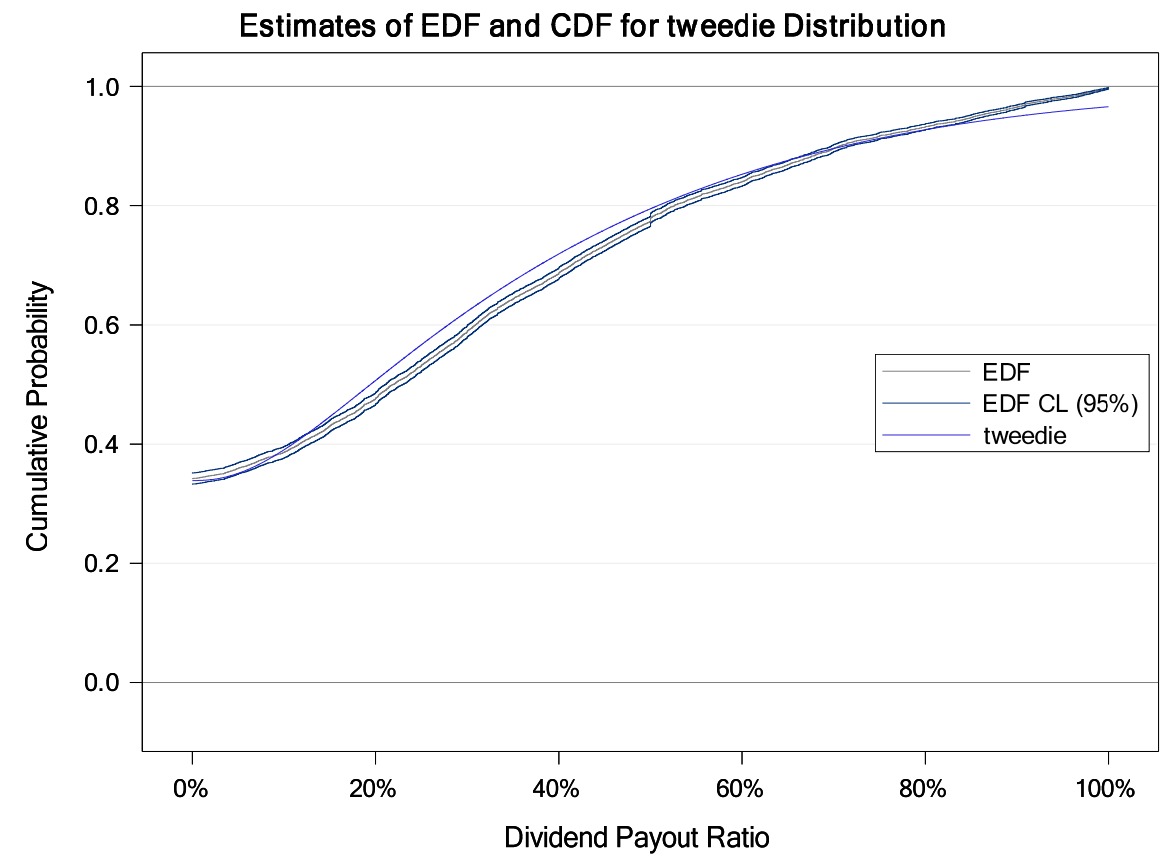

Note: In this figure, CL means confidence limit. 
Figure 4: The conditional probability density function estimates for Tweedie distribution against the empirical distribution: Tweedie distribution is a good choice in approximating the real distribution.

Conditional PDF Estimates for tweedie Distribution
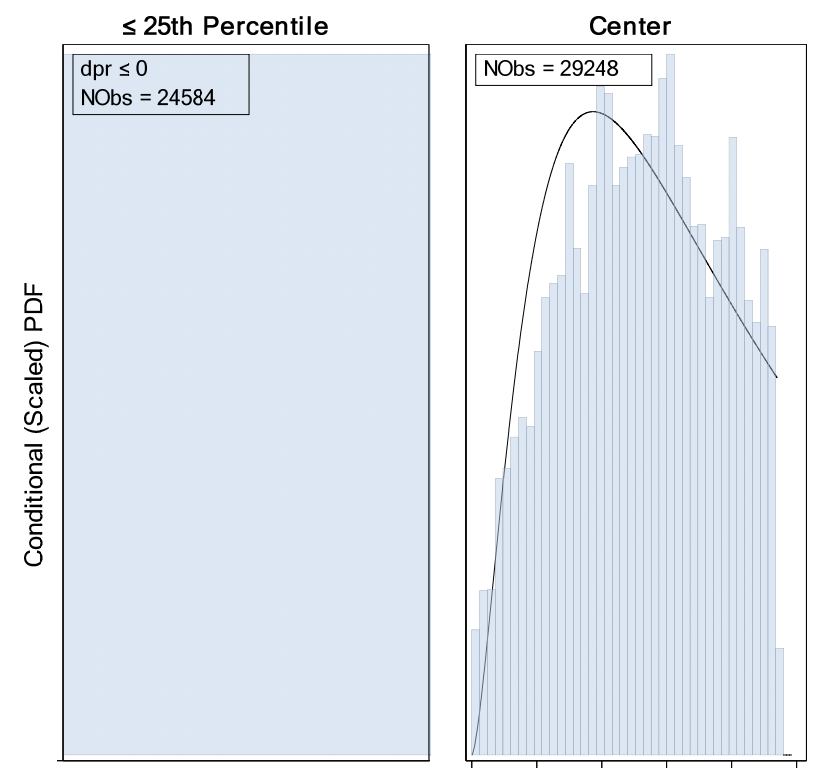

$>$ 75th Percentile

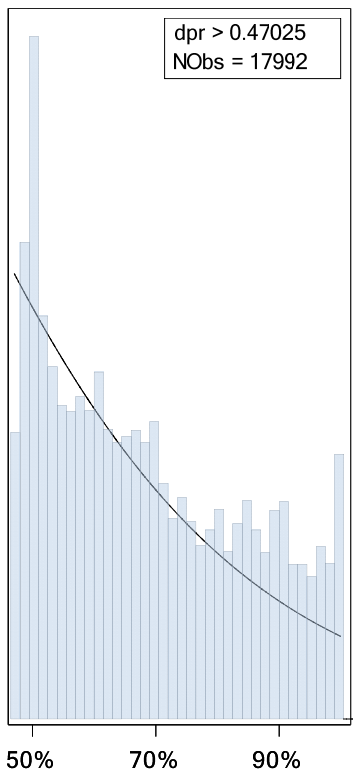

$\begin{array}{llllll}0 \% & 10 \% & 20 \% & 30 \% & 40 \%\end{array}$ Dividend Payout Ratio

Where $k(\mu, p)=\left\{\begin{array}{l}\frac{\mu^{2-p}}{2-p}, \text { for } p \neq 2, \\ \log (\mu), \text { for } p=2\end{array}\right.$, while the function $a(x, \phi)$ has no closed analytical expression.

For $1<p<2$, the Tweedie distribution (denoted here Tweedie $(\mu, \phi, p)$ ) is a compound Poisson-gamma mixture distribution, which is the distribution of $S$ defined as $S=\sum_{i=1}^{N} X_{i}$, where $N \sim$ Poisson $(\lambda)$ and $X_{i} \sim$ gamma $(\alpha, \theta)$ are i.i.d. gamma random variables with shape parameter $\alpha$ and scale parameter $\theta$. The correspondence between these parameters and the parameters of the Tweedie distribution is the following:

$$
\left\{\begin{array}{l}
\lambda=\frac{\mu^{2-p}}{\phi(2-p)} \\
\alpha=\frac{2-p}{p-1} \\
\theta=\phi(p-1) \mu^{p-1}
\end{array} .\right.
$$


The Scaled Tweedie distribution (denoted here STweedie $(\theta, \lambda, p)$ ) is a version of the Tweedie distribution, corresponding to a compound Poisson-gamma distribution with gamma scale parameter $\theta$, Poisson parameter $\lambda$, and the index parameter $p$ such as $\alpha=\frac{2-p}{p-1}$ (Dunn and Smyth 2005).

The correspondence between the parameters of the STweedie $(\theta, \lambda, p)$ distribution and the Tweedie $(\mu, \phi, p)$ distribution is the following:

$$
\left\{\begin{array}{l}
\mu=\lambda \theta \alpha \\
\phi=\frac{(\lambda \theta \alpha)^{2-p}}{\lambda(2-p)}=\frac{\theta}{(p-1)(\lambda \theta \alpha)^{p-1}} .
\end{array}\right.
$$

The Tweedie distribution has nonnegative support and can have a discrete mass at zero, making it useful to model responses that are a mixture of zeros and positive values, just like the empirical distribution of DPR (see Figures 1-4). Hence, we will describe the behaviour of DPR using the Tweedie distribution.

We have estimated the parameters of the Tweedie distribution for the complete database, using numerical method for the maximum likelihood estimator of extra parameter of variance, mean and dispersion parameter. A detailed description of the method is given in Gilchrist and Drinkwater (1999). This method has been implemented in SAS 9.3 and we have used the proc severity procedure for this. The results of the estimation are presented in Table 5.

By analysing the parameters of the estimated Tweedie distribution, several conclusions can be drawn. Firstly, the value of extra parameter controlling for variance is significantly different from zero, as it would be the case if DPR follows a Gaussian distribution. Moreover, $1<p<2$, so the distribution of dividend payout ratio is in fact a compound Poisson-gamma distribution. ${ }^{14} \mathrm{~A}$ compound Poisson random variable $\mathrm{Y}$ is the sum of $N$ independent gamma random variables where $\mathrm{N}$ follows a Poisson distribution and $N$ and the gamma random variates are independent. The distribution of DPR is stable in time, the parameters of the yearly Tweedie distribution being significant and in line with the values estimated for the entire time-period (see Table 6).

For the majority of countries in our sample, DPR follows either a Tweedie distribution or a Scaled Tweedie (STweedie) distribution. This may be a sign of systematic behaviour, regardless of country. The exceptions are Côte d'Ivoire, Luxembourg and Latvia. In the map below, the distribution for each country is presented (see Figure 5). In Appendix 4, the estimated parameters of the Tweedie and Scaled Tweedie distribution by country are shown.

The finding that the Dividend Payout Ratio follows a Tweedie distribution can be have practical applications; for example, one can use the fitted distribution in order to have better estimates of the probability that a certain event will occur (e.g., DPR to be lower or higher than a benchmark).

\footnotetext{
14 This is the most used case in practice, when the Tweedie random variable can be generated from a Poisson gamma distribution (see Smyth 1996).
} 
Economics: The Open-Access, Open-Assessment E-Journal 13 (2019-45)

Table 5: Parameter Estimates for Tweedie Distribution (entire period 2008-2014)

\begin{tabular}{lllllll}
\hline Parameter & DF & Estimate & $\begin{array}{l}\text { Standard } \\
\text { Error }\end{array}$ & t Value & Approx. Pr $>|\mathbf{t}|$ \\
\hline$p \quad$ (extra parameter & of & 1 & 1.279 & 0.002 & 719.830 & $<.0001$ \\
variance) & & 1 & 0.277 & 0.001 & 235.680 & $<.0001$ \\
$\mu$ (mean) & 1 & 0.509 & 0.003 & 158.590 & $<.0001$ \\
$\phi$ (dispersion parameter) & 1 & & & & \\
\hline
\end{tabular}

Source: Own calculation using SAS 9.3

Table 6: Parameter Estimates for Tweedie Distribution by year

\begin{tabular}{llllllll}
\hline Parameter & $\mathbf{2 0 0 8}$ & $\mathbf{2 0 0 9}$ & $\mathbf{2 0 1 0}$ & $\mathbf{2 0 1 1}$ & $\mathbf{2 0 1 2}$ & $\mathbf{2 0 1 3}$ & $\mathbf{2 0 1 4}$ \\
\hline$p$ (extra parameter of variance) & 1.252 & 1.277 & 1.287 & 1.292 & 1.283 & 1.274 & 1.271 \\
$\mu$ (mean) & 0.283 & 0.274 & 0.275 & 0.274 & 0.277 & 0.276 & 0.280 \\
$\phi$ (dispersion parameter) & 0.466 & 0.513 & 0.514 & 0.538 & 0.528 & 0.508 & 0.465 \\
\hline
\end{tabular}

Figure 5: Dividend Payout Ratio's Type of Distribution across Countries

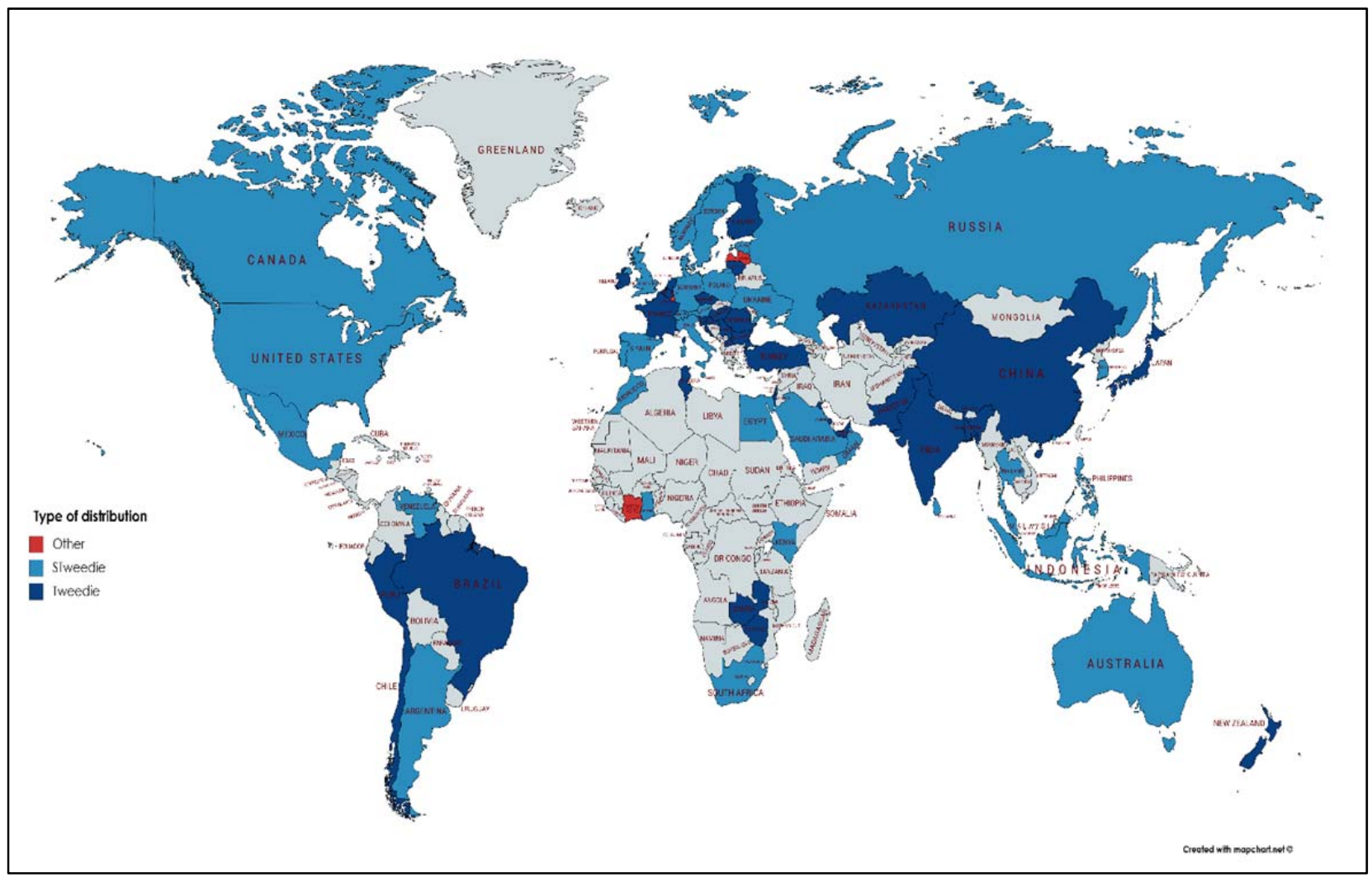




\section{Conclusions}

Dividend policy is still a largely discussed issue in corporate finance literature. For its analysis, dividend payout ratio has certain advantages and is extensively used. Using a database consisting of 12,085 companies operating in 73 countries, for the period 2008-2014, we found that this indicator does not follow a normal distribution, but a zero-inflated one. The most appropriate distribution for modelling dividend payout ratio is the Tweedie distribution (Tweedie 1984) and its version Scaled Tweedie Distribution (Dunn and Smyth 2005). Thus, a better estimation of the probability that dividend payout ratio is lower or higher than a benchmark can be provided. Also, an analysis of dividend policy, distinctly considering payer versus non-payer companies, can offer additional important information for practitioners and, also, for academics. The use of the average levels of dividend payout ratio can determine misleading results. As far as we know, finding the distribution for DPR is a new contribution for financial literature.

Another contribution, comparative to previous research, is the large number of countries considered (73) and covering a crisis and a post-crisis period (2008-2014). Our sample included countries from Africa, North and South Americas, Asia, Australia, and Europe. From here, conclusions are validated for countries with a large diversity regarding the cultural values, but also legal systems (our sample includes common law, but also civil law countries).

This outcome could be useful in the future research where a more appropriate distribution could be used for modelling the influencing factors of the DPR. Based on our knowledge, our paper is the first one that tried to investigate which would be the most appropriate distribution function for DPR. Our result can be useful in the context of international portfolio management, especially when we discuss about investments made in a large number of companies (with minority participations), and when forecasting of the future collected dividends is of interest.

As a limitation of the study, our analysis and results are made on only one financial indicator that describe dividend policy - dividend payout ratio. One interesting extension can be made analyzing other indicators reflecting the dividend policy, too. Also, accounting rules are different from country to country (Chui et al. 2002; Dragotă et al. 2018) and from sector to sector (Short et al 2002). Fiscal systems are also different and they can have an impact on financial decisions (Chui et al. 2002, Dragotă et al. 2018), including dividend policy (Short et al 2002, Fidrmuc and Jacob 2010). These issues can have an impact on earnings (La Porta et al. 2000), and, from here, on dividend payout ratio.

Acknowledgements We would like to thank the anonymous referee of this study, who provided very valuable observations. Also, we wish to thank to Dan Anghel, Andreea Curmei-Semenescu, Bogdan Negrea, and Mădălina Ecaterina Popescu, for their useful comments. We also wish to thank to the participants to the $19^{\text {th }}$ Annual Conference on Finance and Accounting organised by the Faculty of Finance and Accounting, University of Economics, Prague (25 May 2018), and especially to David Prochazka, Marcio Fernandes Gabrielli, and Jan Hospodka. The remaining errors are ours. 


\section{References}

Aivazian, V., Booth, L., and Cleary, S. (2003). Do Emerging Market Firms Follow Different Dividend Policies from U.S. Firms? The Journal of Financial Research, 26(3), 371-387. https://doi.org/10.1111/1475-6803.00064

Anderson, T.W., and Darling, D.A.A. (1954). Test of Goodness-of-Fit. Journal of American Statistical Association, 49, 765-769.

http://www.hep.caltech.edu/ fcp/statistics/hypothesisTest/PoissonConsistency/AndersonDarling19 54.pdf

Arnott, R., and Asness, C. (2003). Surprise! Higher Earnings Growth. Financial Analysts Journal, 59(1), 70-87. https://www.tandfonline.com/doi/abs/10.2469/faj.v59.n1.2504

Baker, K.H., and Weigand, R. (2015). Corporate Dividend Policy Revisited. Managerial Finance, 41(2), 126-144. https://www.emeraldinsight.com/doi/abs/10.1108/MF-03-2014-0077

Baker, K.H., Chang, B., Dutta, S., and Saadi, S. (2012). Why Firms do not pay Dividends: the Canadian Experience. Journal of Business Finance \& Accounting, 399(10), 1330-1356. https://onlinelibrary.wiley.com/doi/abs/10.1111/jbfa.12005

Banyi, M.L., and Kahle, K.M. (2014). Declining Propensity to pay? A Re-examination of the Lifecycle Theory. Journal of Corporate Finance 27, 345-366.

https:/www.sciencedirect.com/science/article/pii/S0929119914000698

Bena, J., and Hanousek, J. (2008). Rent Extraction by Large Shareholders: Evidence Using Dividend Policy in the Czech Republic. Finance a úvěr-Czech Journal of Economics and Finance, 58, 106130. http://journal.fsv.cuni.cz/storage/1125_str_106_130--bena-hanousek.pdf

Bhattacharya, S. (1979). Imperfect Information, Dividend Policy, and the Bird in Hand Fallacy. The Bell Journal of Economics, 10(1), 259-270.

https://econpapers.repec.org/article/rjebellje/v_3a10_3ay_3a1979_3ai_3aspring_3ap_3a259270.htm

Bonat, W.H., and Kokonendji, C.C. (2017). Flexible Tweedie Regression Models for Continuous Data. Journal of Statistical Computation and Simulation 87(11), 2138-2152. http://www.leg.ufpr.br/ wagner/Articles/BONAT_JSCS_2017.pdf

Chen, J., Leung, W.S., and Goergen, M. (2017). The Impact of Board Gender Composition on Dividend Payouts. Journal of Corporate Finance, 43, 86-105.

https:/www.sciencedirect.com/science/article/pii/S0929119917300020

Chen, S., and Desiderio, S. (2018). What moves the Beveridge curve and the Phillips curve: an agentbased analysis. Economics: The Open-Access, Open-Assessment E-Journal, 12 (2018-2): 1-30. http://dx.doi.org/10.5018/economicsejournal.ja.2018-2

Chui, A.C.W., Lloyd, A.E., and Kwok, C.C.Y. (2002). The Determination of Capital Structure: Is National Culture a Missing Piece to the Puzzle? Journal of International Business Studies, 33(1), 99-127. https://link.springer.com/article/10.1057/palgrave.jibs.8491007

Cincotti, S., Raberto, M., and Teglio, A. (2010). Credit Money and Macroeconomic Instability in the Agent-based Model and Simulator Eurace. Economics: The Open-Access, Open-Assessment EJournal, 4 (2010-26): 1-32. http://dx.doi.org/10.5018/ economics-ejournal.ja.2010-26 
Clauset, A., Shalizi, C. R., and Newman, M.E.J. (2009). Power-law Distributions in Empirical Data. SIAM Review 51(4), 661-703. https://epubs.siam.org/doi/abs/10.1137/070710111

DeAngelo, H., and DeAngelo, L. (1990). Dividend Policy and Financial Distress: An Empirical Investigation of Troubled NYSE Firms. Journal of Finance, 45(5), 1415-1431. https://onlinelibrary.wiley.com/doi/abs/10.1111/j.1540-6261.1990.tb03721.x

Denis, D.J., and Osobov, I. (2008). Why do Firms pay Dividends? International Evidence on the Determinants of Dividend Policy. Journal of Financial Economics, 89(1), 62-82. https://www.sciencedirect.com/science/article/abs/pii/S0304405X08000445

Desai, M.A., and Jin, L. (2011). Institutional Tax Clienteles and Payout Policy. Journal of Financial Economics 100(1), 68-84.

https://www.sciencedirect.com/science/article/abs/pii/S0304405X10002497

Dragotă I.M., Dragotă V., Curmei-Semenescu A., and Pele D.T. (2018). Religion and Capital Structure: Some International Evidences. Acta Oeconomica 68(3), 415-442. https://akademiai.com/doi/abs/10.1556/032.2018.68.3.5

Dunn, P.K., and Smyth, G.K. (2005). Series Evaluation of Tweedie Exponential Dispersion Model Densities. Statistics and Computing 15(4), 267-280. https://link.springer.com/article/10.1007/s11222-005-4070-y

Easterbrook, F.H. (1984). Two Agency-Cost Explanations of Dividends. American Economic Review 74(4), 650-659. https://econpapers.repec.org/article/aeaaecrev/v_3a74_3ay_3a1984_3ai_3a4_3ap_3a650-59.htm

El-Shaarawi, A.H., Zhu, R., and Joe, H. (2011). Modelling Species Abundance Using the PoissonTweedie Family. Environmetrics 22(2), 152-164. https://onlinelibrary.wiley.com/doi/abs/10.1002/env.1036

Faccio, M., Lang, L.H.P., and Young, L. (2001). Dividends and Expropriation. American Economic Review, 91(1), 54-78. https://www.aeaweb.org/articles?id=10.1257/aer.91.1.54

Fama, E.F., and French K.R. (2001). Disappearing Dividends: Changing Firm Characteristics or Lower Propensity to pay? Journal of Financial Economics 60(1), 3-43. https://www.sciencedirect.com/science/article/abs/pii/S0304405X01000381

Fatemi, A., and Bildik, R. (2012). Yes, Dividends are disappearing: Worldwide Evidence. Journal of Banking \& Finance 36(3), 662-677. https:/www.sciencedirect.com/science/article/pii/S0378426611002858

Ferris, S., Sen, N., and Unlu, E. (2009). An International Analysis of Dividend Payment Behavior. Journal of Business Finance \& Accounting, 36(3-4), 496-522. https://onlinelibrary.wiley.com/doi/abs/10.1111/j.1468-5957.2009.02126.x

Fidrmuc, J.P., and Jacob, M. (2010). Culture, Agency Cost and Dividends. Journal of Comparative Economics, 38(3), 321-339. https:/www.sciencedirect.com/science/article/pii/S0147596710000260

Floyd, E., Li, N.,S., and Douglas, J. (2015). Payout Policy through the Financial Crisis: The Growth of Repurchases and the Resilience of Dividends. Journal of Financial Economics, 118(2), 299-316. https://www.sciencedirect.com/science/article/abs/pii/S0304405X15001415 
Gilchrist, R., and Drinkwater, D. (1999). Fitting Tweedie Models to Data with Probability of Zero Responses. Proceedings of the 14th International Workshop on Statistical Modelling, 207-214. https://ink.springer.com/chapter/10.1007/978-3-642-57678-2_39

Graham, B., and Dodd, D. (1951). Security Analysis. $3^{\text {rd }}$ ed. New York, McGraw-Hill, Book Company, New York.

He, W., Ng, L., Zaiats, N., and Zhang, B. (2017). Dividend Policy and Earnings Management across Countries. Journal of Corporate Finance, 42, 267-286.

https://www.sciencedirect.com/science/article/pii/S0929119916303182

Hofstede, G. (2001). Culture's Consequences: Comparing Values, Behaviors, Institutions, and Organizations across Nations. Beverly Hills CA: Sage.

Holder, M., Langrehr, F., and Hexter, L. (1998). Dividend Policy Determinants: An Investigation of the Influences of Stakeholder Theory. Financial Management, 27(3), 73-82.

https://papers.ssrn.com/sol3/papers.cfm?abstract_id=143689

Huang, T., Wu, F., Yu, J., and Zhang, B. (2015). Political Uncertainty and Dividend Policy: Evidence from International Political Crises. Journal of International Business Studies, March 2015, 1-22. http://ifas.xmu.edu.cn/uploads/soft/130426/paper.pdf

Jäntschi, L., and Bolboacă S.D. (2018). Computation of Probability Associated with Anderson-Darling Statistic. Mathematics - Open Access Journal, 6(6), 88. https://doi.org/10.3390/math6060088

Jiang, F., Ma, Y., and Shi, B. (2017). Stock Liquidity and Dividend Payouts. Journal of Corporate Finance, 42, 295-314.

https://www.sciencedirect.com/science/article/pii/S0929119916303583

Jørgensen, B., and Kokonendji, C.C. (2016). Discrete Dispersion Models and their Tweedie Asymptotics. AStA Advances in Statistical Analysis 100(1), 43-78. https://link.springer.com/article/10.1007/s10182-015-0250-z

Jørgensen, B., Paes De Souza, M.C. (1994). Fitting Tweedie's Compound Poisson Model to Insurance Claims Data. Scandinavian Actuarial Journal 1, 69-93. https://www.tandfonline.com/doi/abs/10.1080/03461238.1994.10413930

Kalay, A. (1980). Signalling, Information Content and the Reluctance to cut Dividends. Journal of Financial and Quantitative Analysis, 15(4), 855-869. http://ecsocman.hse.ru/data/909/126/1231/kalay___signaling_1980.pdf

Kuo, J., Philip, D., Zhang, Q. (2013). What drives the Disappearing Dividends Phenomenon? Journal of Banking \& Finance 37(9), 3499-3514.

https://www.sciencedirect.com/science/article/pii/S0378426613002215

Kurz, C. (2017). Tweedie Distributions for Fitting Semicontinuous Health Care Utilization Cost Data. BMC Medical Research Methodology 17, 171, 1-8. https://bmcmedresmethodol.biomedcentral.com/articles/10.1186/s12874-017-0445-y

La Porta, R., Lopez-de-Silanes, F., Shleifer, A., and Vishny, R.W. (2000). Agency Problems and Dividend Policies around the World. Journal of Finance, 55(1), 1-33. https://onlinelibrary.wiley.com/doi/10.1111/0022-1082.00199

Lamont, O. (1998). Earnings and Expected Returns. Journal of Finance 53(5), 1563-1587. https://onlinelibrary.wiley.com/doi/abs/10.1111/0022-1082.00065 
Lettau, M., and Ludvinson, S. (2001). Consumption, Aggregate Wealth, and Expected Stock Returns. Journal of Finance 56(3), 815-849. https://onlinelibrary.wiley.com/doi/10.1111/0022-1082.00347

Lintner, J. (1956). Distribution of Incomes of Corporations among Dividends, Retained Earnings and Taxes. American Economic Review 46(2), 97-113.

Miller, M.H., and Modigliani, F. (1961). Dividend Policy, Grow and the Valuation of Share. Journal of Business, 34(4), 411-433. https://www2.bc.edu/thomas-chemmanur/phdfincorp/MF891\%20papers/MM\%20dividend.pdf

Nicolosi, G. (2013). Demographics of Dividends. Journal of Corporate Finance 23, 54-70. https://www.sciencedirect.com/science/article/pii/S0929119913000606

Pearson, K. (1895). Contribution to the Mathematical Theory of Evolution. II. Skew Variation in Homogenous Material. Philosophical Transactions of the Royal Society of London, 91, 343-414.

Renneboog, L., and Trojanowski, G. (2007). Control Structures and Payout Policy. Managerial Finance, 33(1), 43-64. https://www.emeraldinsight.com/doi/abs/10.1108/03074350710715809

Renshaw, A.E. (1994). Modelling the Claims Process in the Presence of Covariates. ASTIN Bulletin 24, 265-286.

https:/www.cambridge.org/core/services/aop-cambridge-core/content/view/S051503610000283X

Scholz, F.W., Stephens, M.A. (1987). K-Sample Anderson-Darling Tests, Journal of the American Statistical Association, 82(399), 918-924.

https://www.tandfonline.com/doi/abs/10.1080/01621459.1987.10478517

Shao, L., Kwok, C.C.I., and Guedhami, O. (2010). National Culture and Dividend Policy. Journal of International Business Studies, 41, 391-414.

https://link.springer.com/article/10.1057/jibs.2009.74

Short, H., Zhang, H., and Keasey, K. (2002). The Link between Dividend Policy and Institutional Ownership. Journal of Corporate Finance 8(2): 105-122.

https://www.sciencedirect.com/science/article/pii/S092911990100030X

Smyth, G.K. (1996). Regression Analysis of Quantity Data with Exact Zeros. In Proceedings of the Second Australia-Japan Workshop on Stochastic Models in Engineering, Technology, and Management, edited by R. J. Wilson, S. Osaki, and D. N. P. Murthy, 572-580. Queensland, Australia: Technology Management Centre, University of Queensland. https://pdfs.semanticscholar.org/8136/348cd0080641a3eccac2bfdfceec38b0edb5.pdf

Stephens, M.A. (1974). EDF Statistics for Goodness of Fit and Some Comparisons. Journal of the American Statistical Association, 69(347), 730-737. https://www.tandfonline.com/doi/abs/10.1080/01621459.1974.10480196

Tweedie, M.C.K. (1984). An Index which distinguishes between some Important Exponential Families. In J.K. Ghosh and J. Roy (Eds.), Statistics: Applications and New Directions. Proceedings of the Indian Statistical Institute Golden Jubilee International Conference, Calcutta: Indian Statistical Institute.

von Eije, H., and Megginson, W.L. (2008). Dividends and Share Repurchases in the European Union. Journal of Financial Economics 89(2), 347-374.

https:/www.sciencedirect.com/science/article/abs/pii/S0304405X08000949 
Walter, J.E. (1956). Dividend Policies and Common Stock Prices. Journal of Finance, 1(1), 29-41. https://onlinelibrary.wiley.com/doi/full/10.1111/j.1540-6261.1956.tb00684.x

Yaseen, H. (2019). Dividend Policy explained by Country's Standards of Living: An International Evidence. In: D. Procházka (ed.), Global versus Local Perspectives on Finance and Accounting. Springer Proceedings in Business and Economics, Springer Nature, Switzerland AG 2019. https://link.springer.com/chapter/10.1007\%2F978-3-030-11851-8_12

Yaseen, H., and Dragotă, V. (2019). Harmony, Hierarchy and Dividend Policy around the World. In: D. Procházka (ed.), Global versus Local Perspectives on Finance and Accounting. Springer Proceedings in Business and Economics, Springer Nature, Switzerland AG 2019. https://link.springer.com/chapter/10.1007\%2F978-3-030-11851-8_11

Ye, D., Deng, J., Liu, Y., Szewczyk, S., and Chen, X. (2019). Does Board Gender Diversity increase Dividend Payouts? Analysis of Global Evidence. Journal of Corporate Finance, 58, 1-26. https://www.sciencedirect.com/science/article/pii/S0929119918300312

Zheng, C., and Ashraf, B.N. (2014). National Culture and Dividend Policy: International Evidence from Banking. Journal of Behavioral and Experimental Finance 3, 22-40.

https://www.sciencedirect.com/science/article/abs/pii/S2214635014000392 


\section{Appendix 1: Dividend payout ratio on the world: some descriptive statistics}

Figure A.1.1: Dividend payout ratio for the companies included in the sample (per country), in the period 2008-2014. All companies' financials were collected from the Thomson Research Worldscope database. DPR is computed as: $\boldsymbol{D P R}=\frac{\text { Dividends }}{\text { Net income }}$.

Country 1 - Argentina

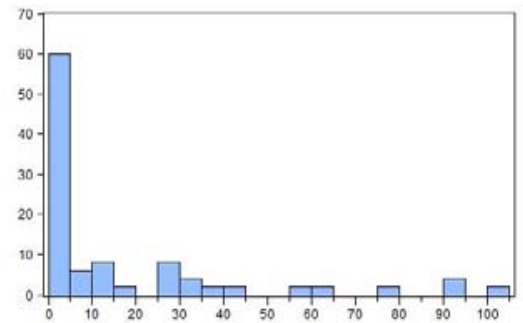

Country 3 - Austria

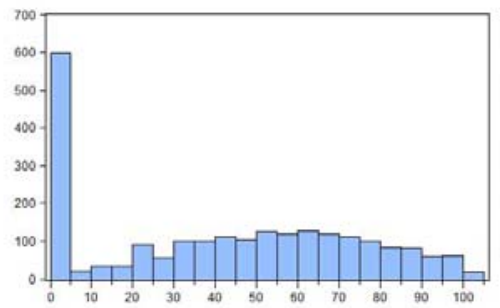

Country 5 - Bangladesh

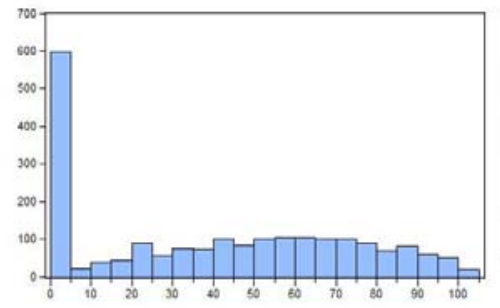

Country 2 - Australia
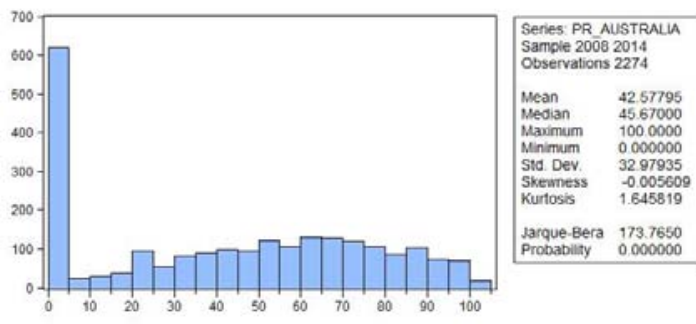

Country 4 - Bahrein
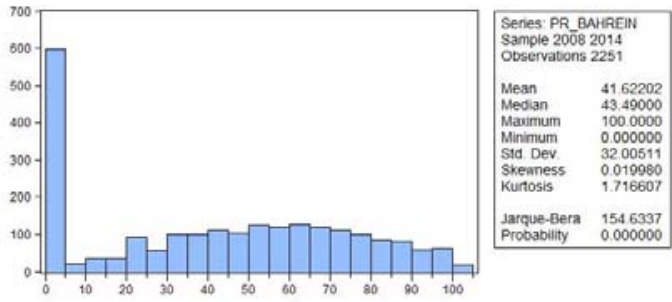

Country 6 - Belgium
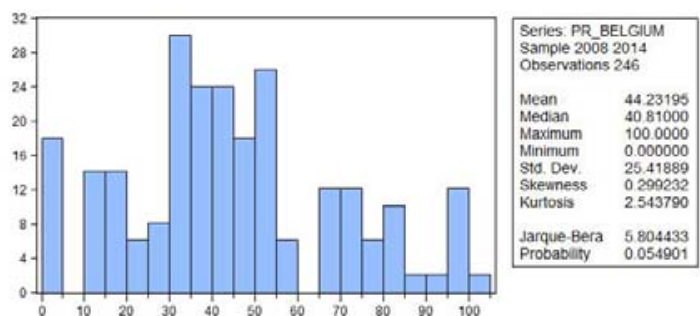
Country 7 - Brazil

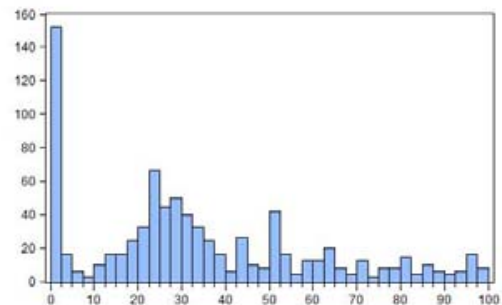

Country 9 - Canada

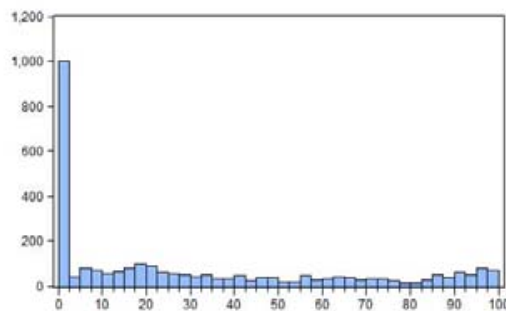

Country $11-$ China

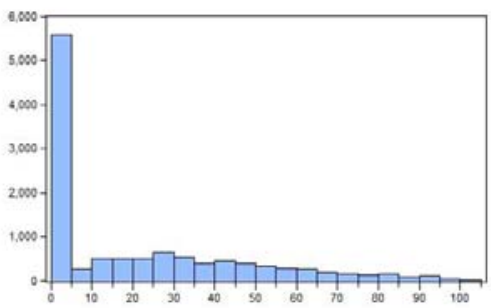

Country 13 - Croatia

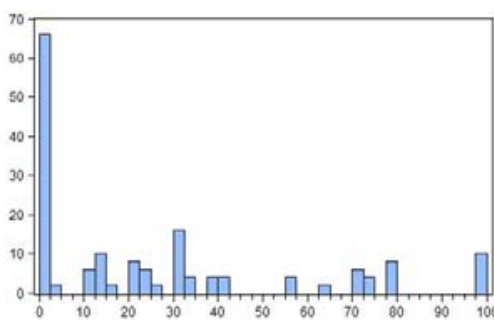

Country 8 - Bulgaria
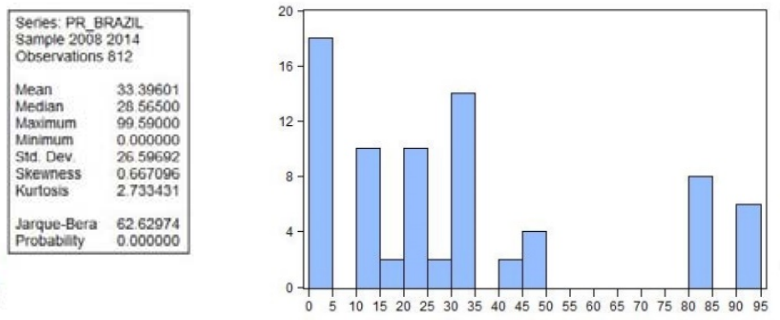
Series: PR_Bulgaria
Sample 20082014 Observations 76

\begin{tabular}{ll} 
& 32.22184 \\
\hline & Mean
\end{tabular} Maximum 29.65694
ta. Dev. $\quad 273569$ $\begin{array}{ll} & \\ \text { Kurtosis } & 2.782667 \\ & 2.73693\end{array}$ \begin{tabular}{ll} 
& \\
Jarque-Bera & 12.45594 \\
Probability & 0.001973 \\
\hline
\end{tabular}
Country $10-$ Chile

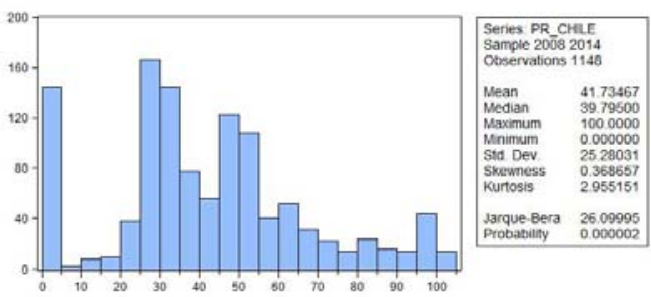

Country 12 - Cote d'Ivoire

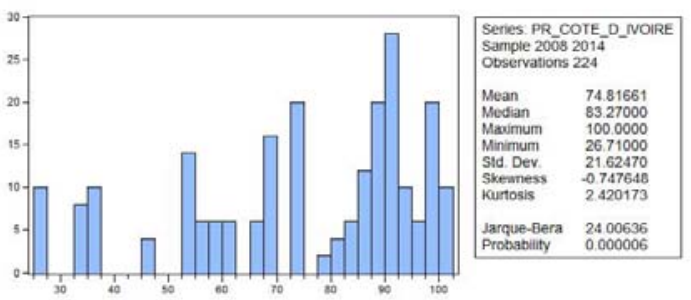

Country 14 - Czech Republic
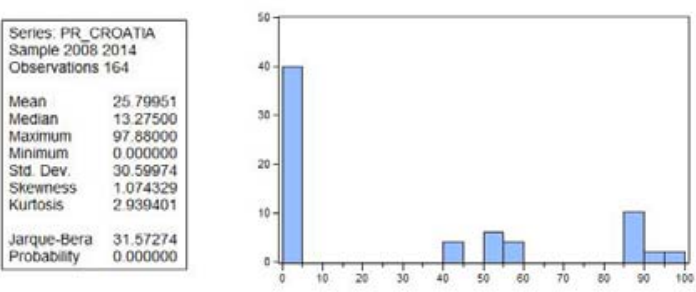
Country 15 - Denmark

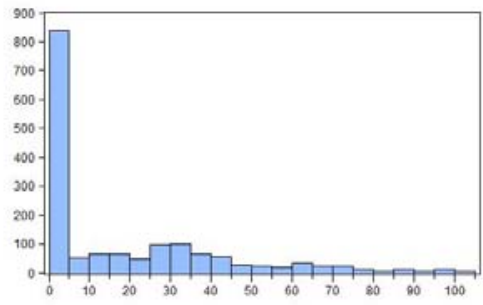

Country 17 - Estonia

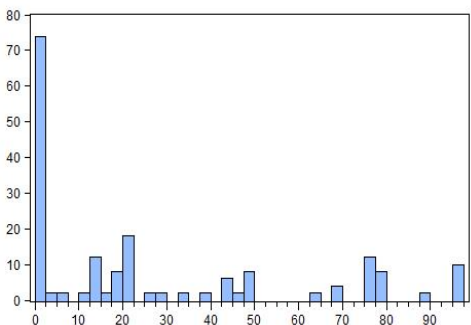

Country 19 - France

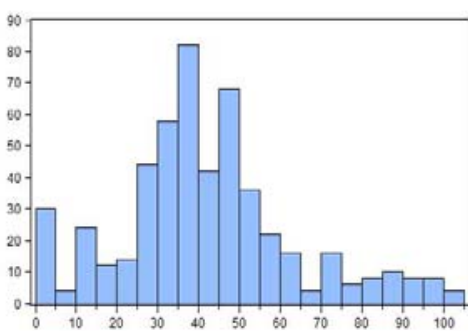

Country $21-$ Ghana

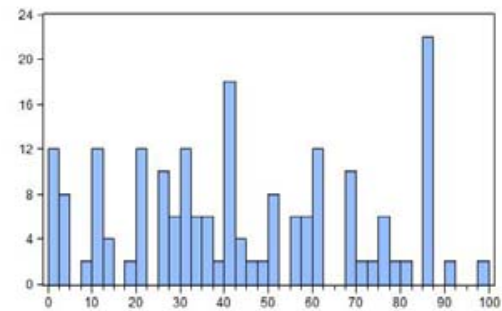

Country 16 - Egypt
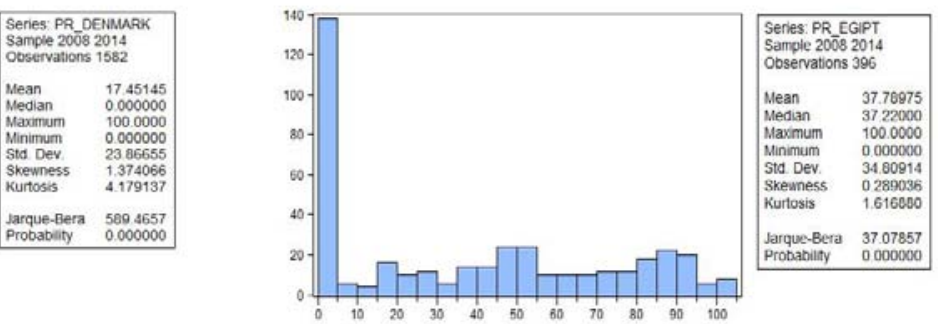

Country 18 - Finland
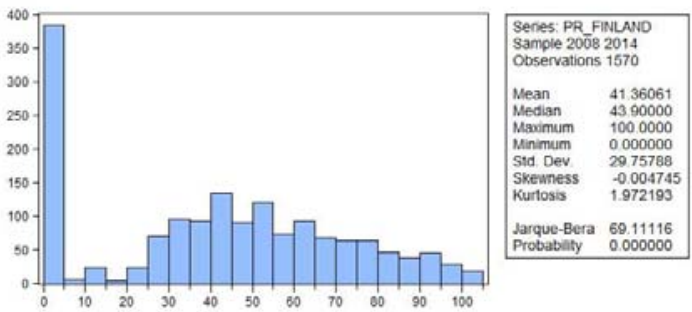

Country 20 - Germany
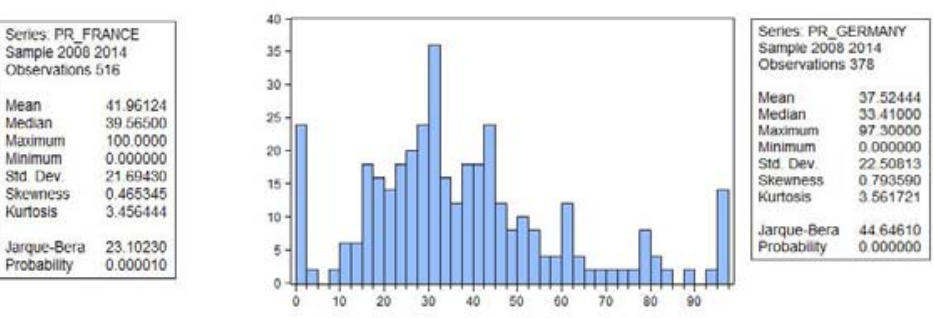

Country $22-$ Greece

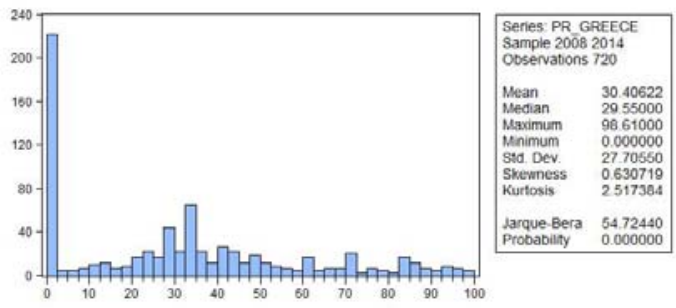


Country 23 - Hong Kong

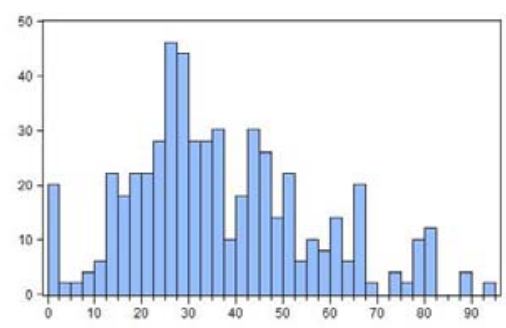

Country 25 - India

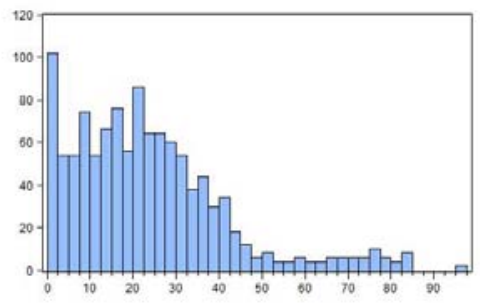

Country 27 - Ireland

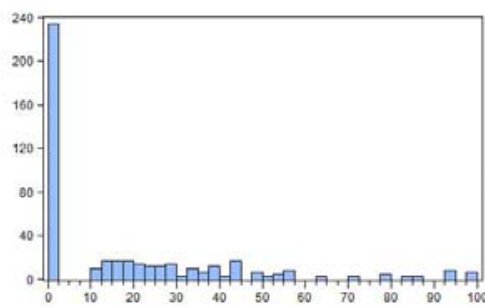

Country 29 - Italy

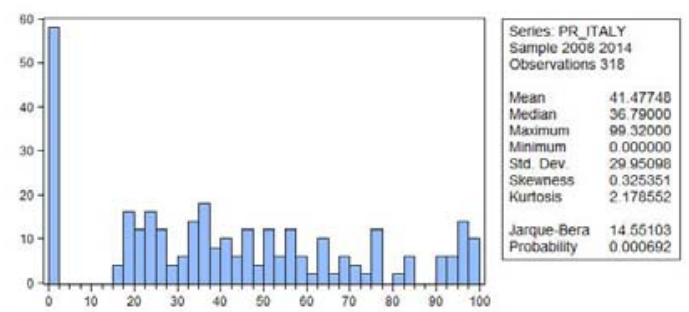

Country $24-$ Hungary

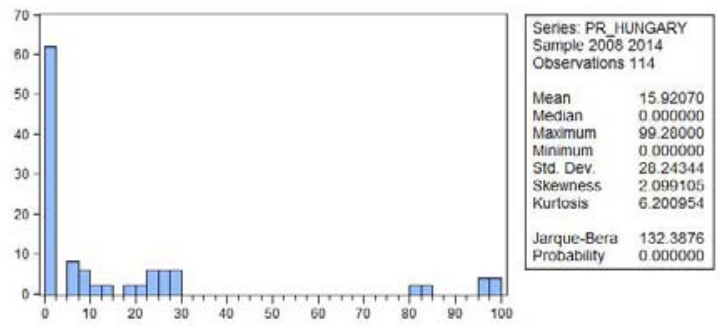

Country 26 - Indonesia
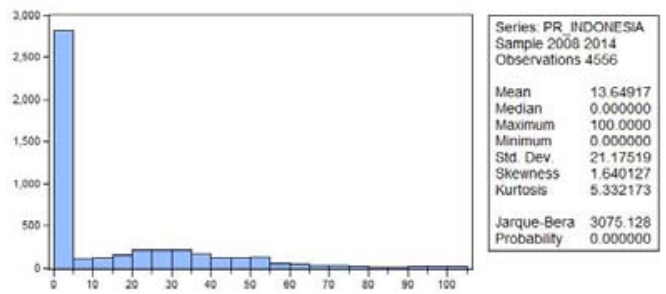

Country 28 - Israel
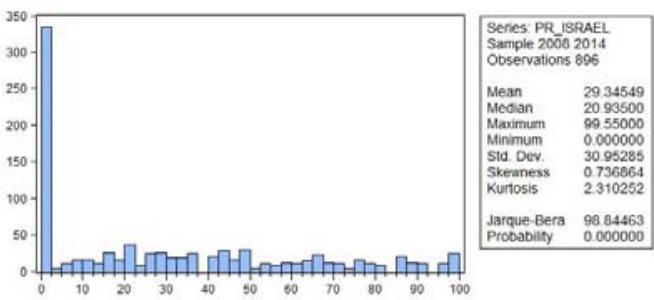

Country 30 - Japan
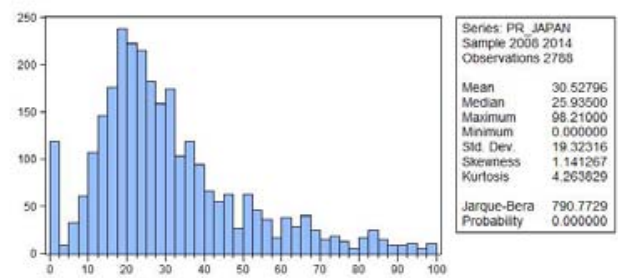
Country 31 - Kazakhstan

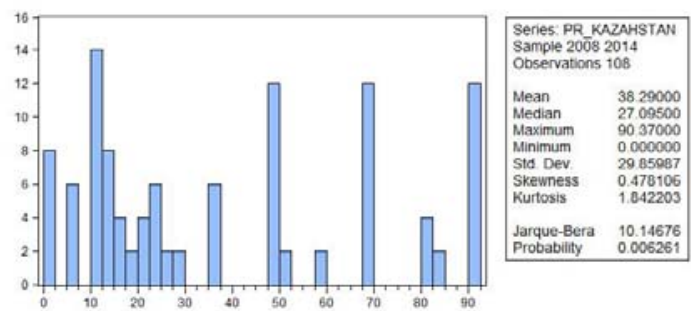

Country 33 - Kuwait

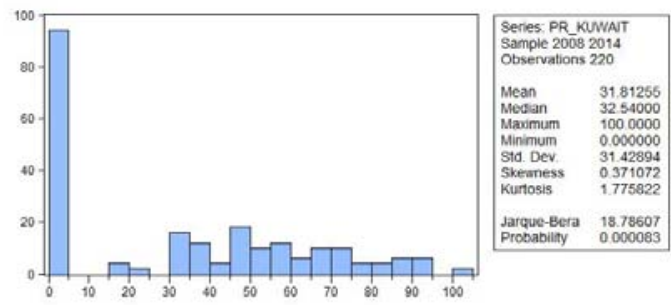

Country 35 - Lithuania
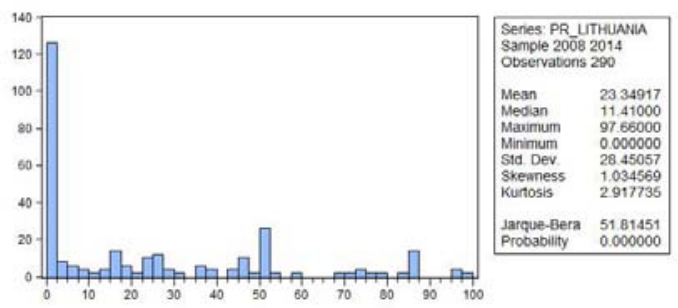

Country $32-$ Kenya

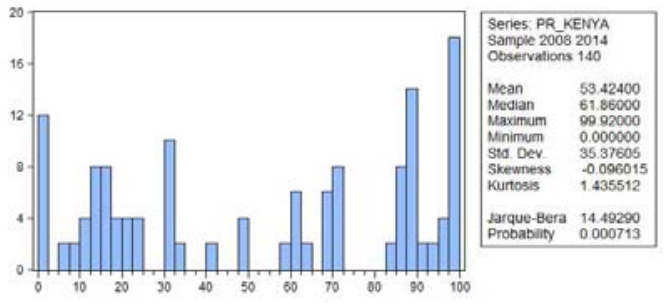

Country $34-$ Latvia

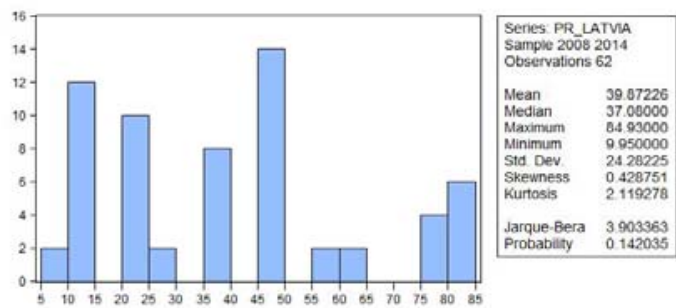

Country 36 - Luxembourg

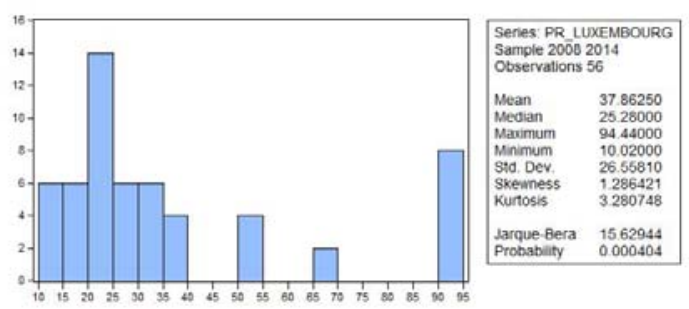

Country 37 - Former Yugoslav Republic of Country 38-Malaysia Macedonia

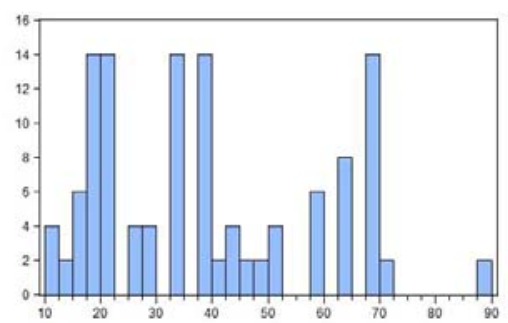

\section{Country $38-$ Malaysia}
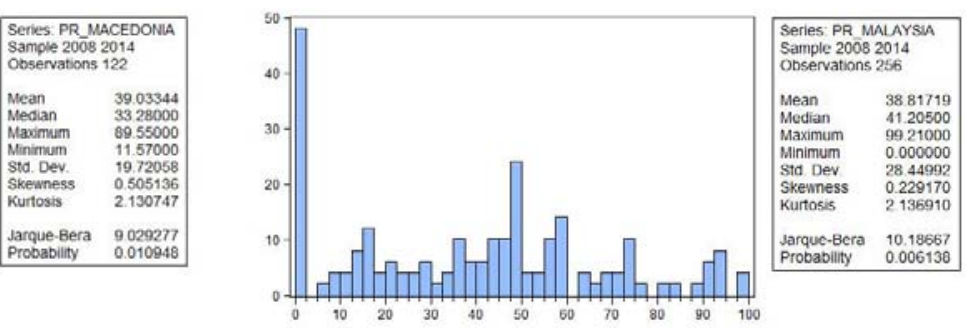
Country 39 - Malta

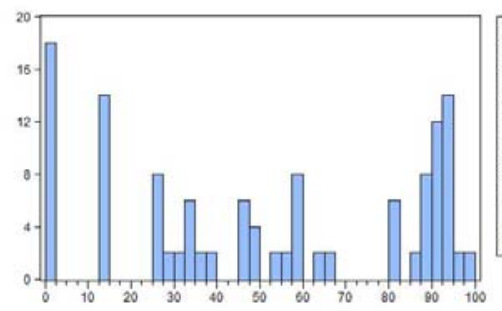

Country $41-$ Mexico

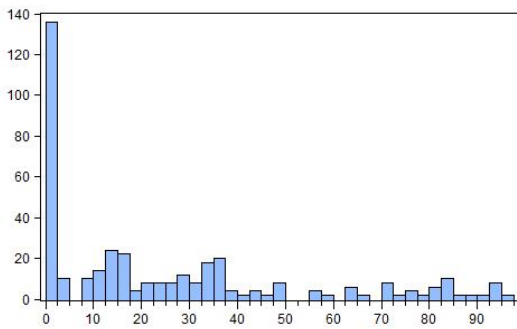

Country 43 - Netherlands

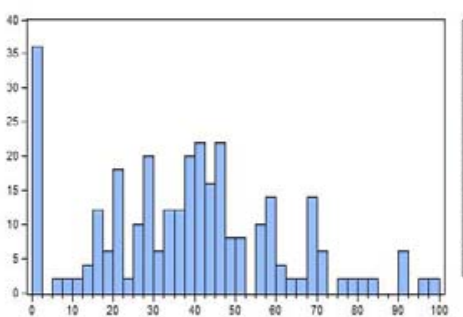

Country 45 - Norway

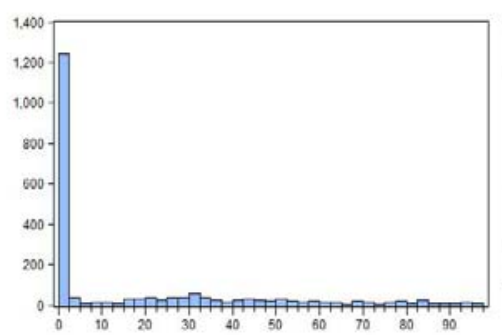

Country 40 - Mauritius

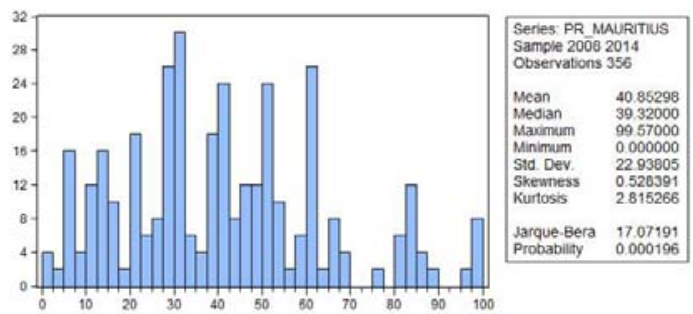

Country $42-$ Morocco
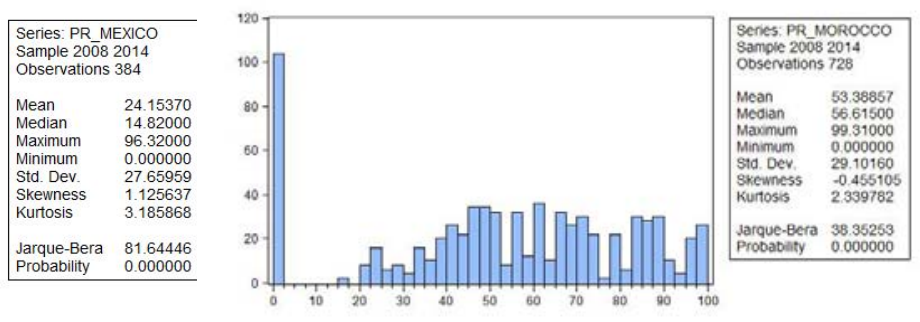

Country 44 - New Zealand
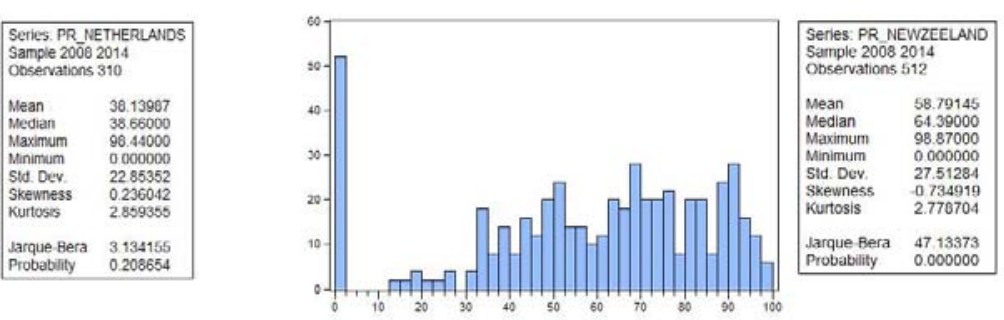

Country 46 - Oman
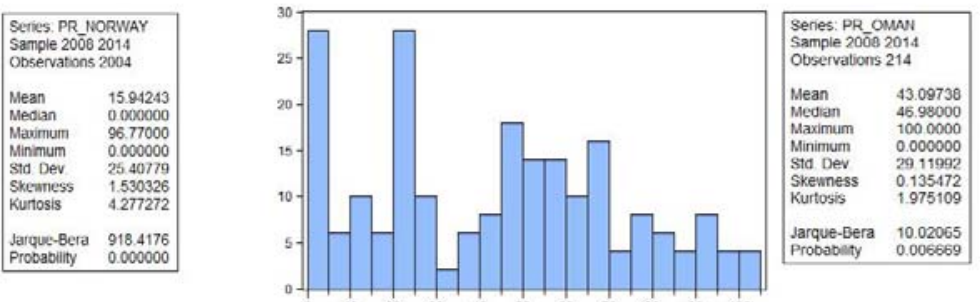
Country 47 - Pakistan

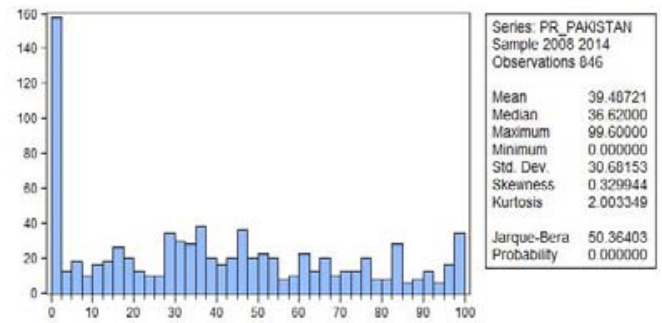

Country 49 - Peru

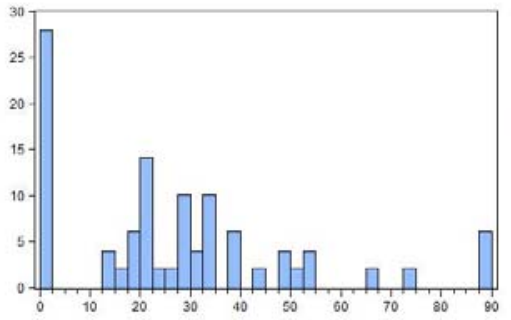

Country 51 - Poland

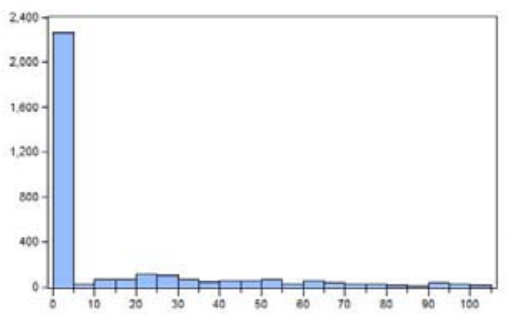

Country 53 - Romania

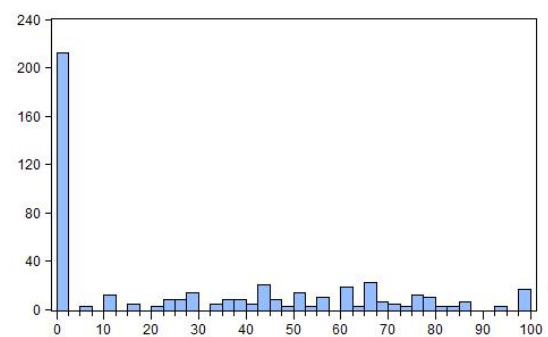

Country 48 - Palestine

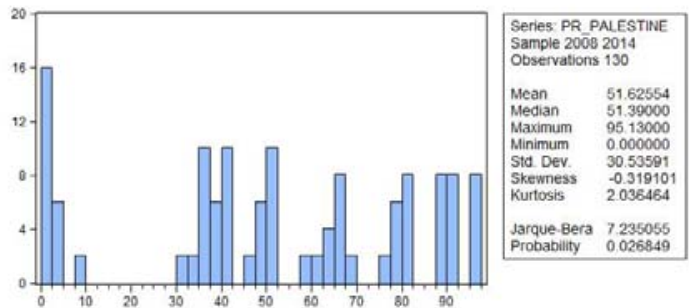

Country 50 - Philippines
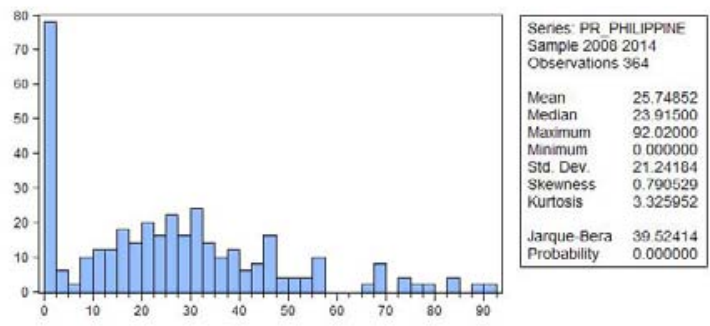

Country 52 - Portugal
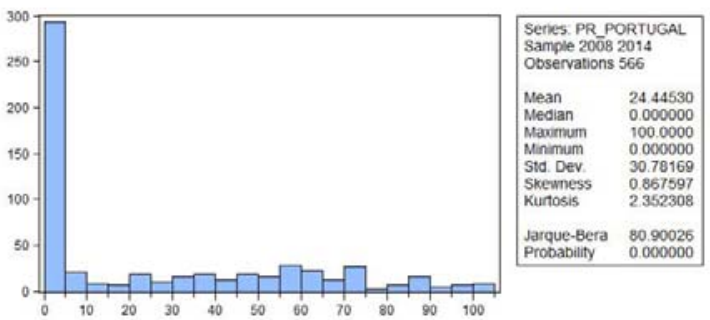

Country $54-$ Russia
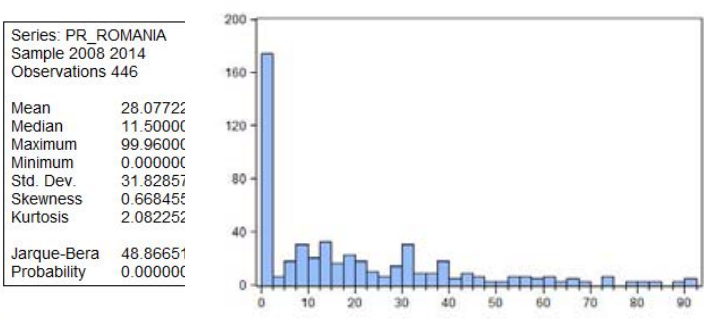
Country 55 - Saudi Arabia
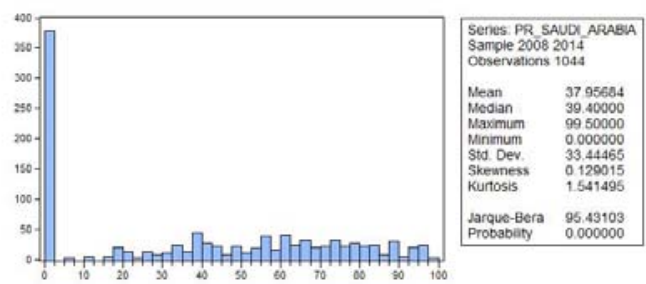

Country 57 - Slovenia

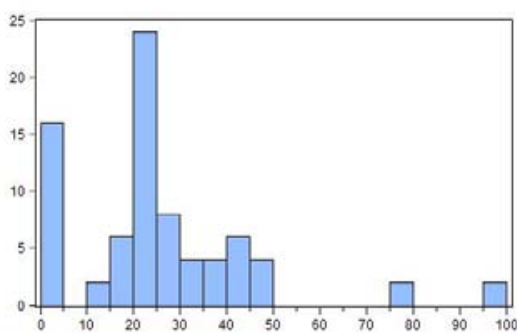

Country 59 - South Korea

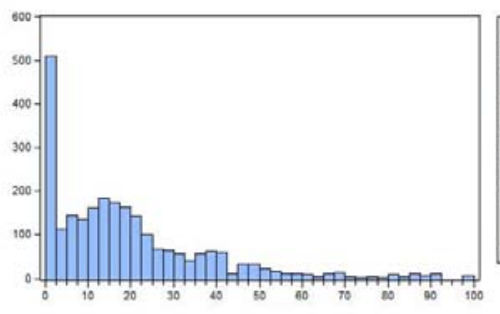

Country 61 - Sri Lanka

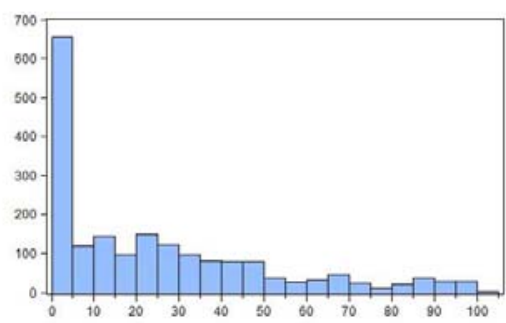

Country 56 - Serbia

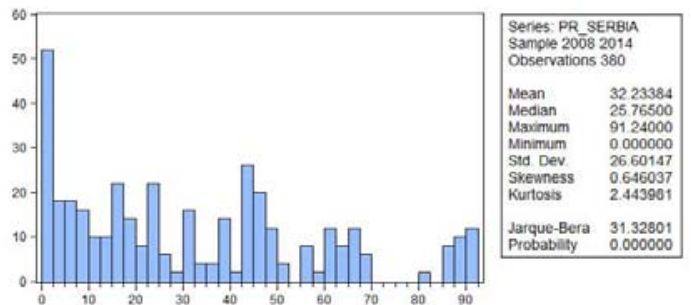

Country 58 - South Africa
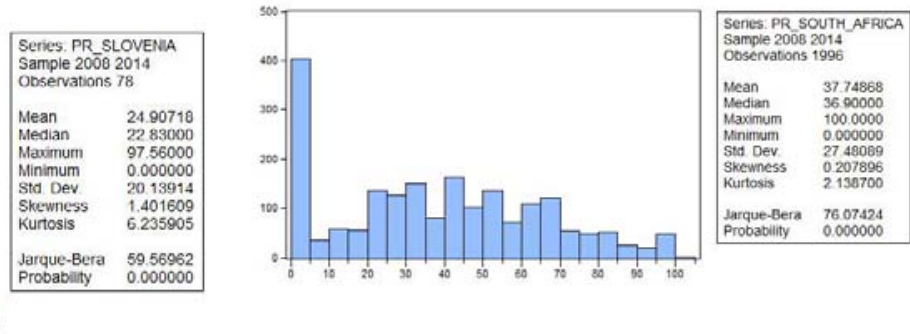

Country 60 - Spain
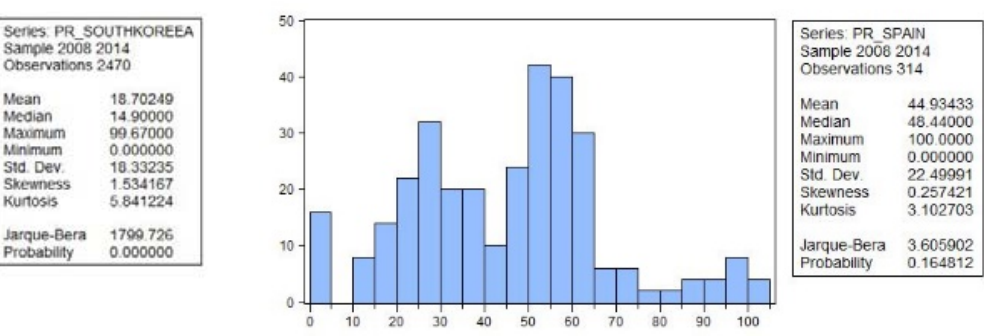

Country $62-$ Sweden
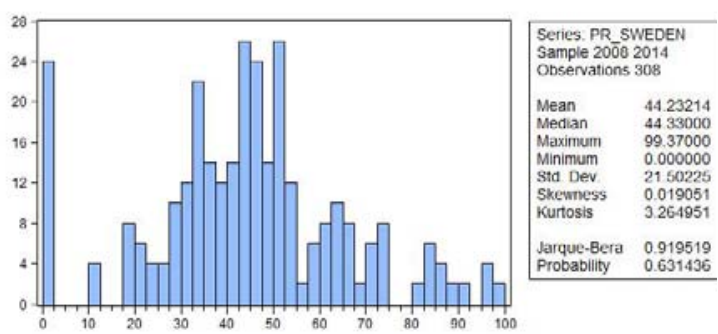
Country 63 - Switzerland

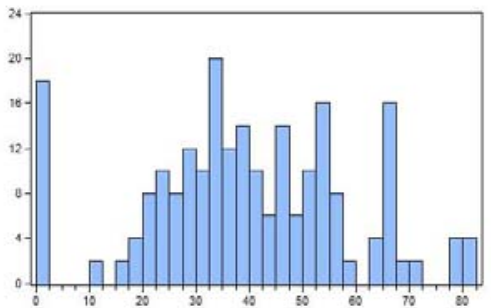

Country 65 - Tunisia

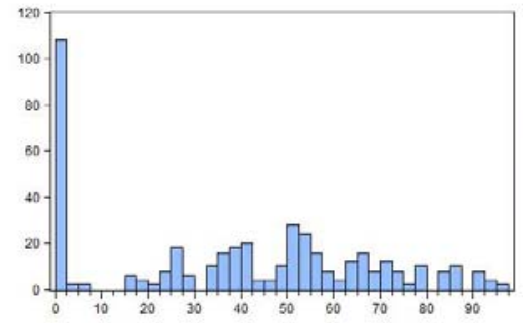

Country 67 - Ukraine
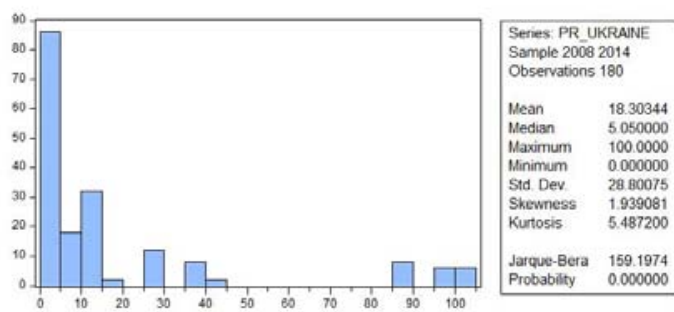

Country 69 - United Kingdom

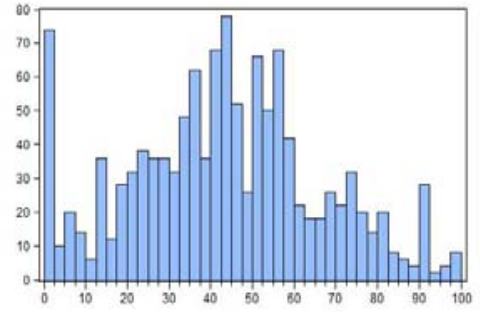

Country 64 - Thailand
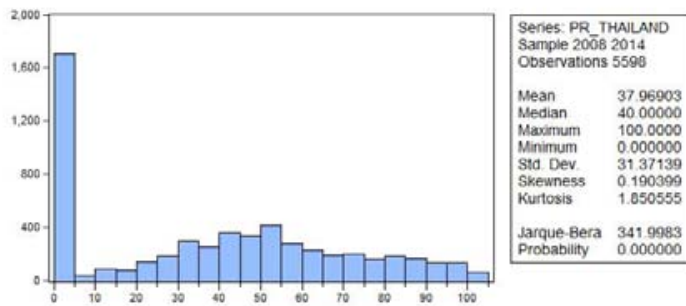

Country 66 - Turkey
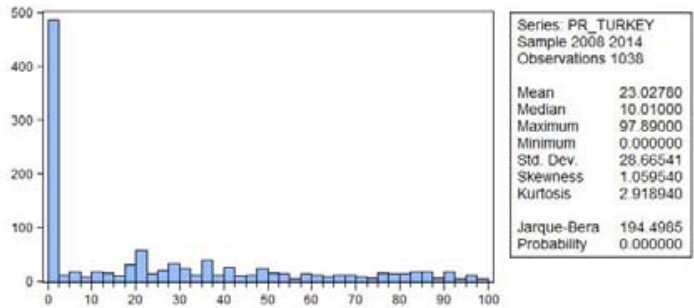

Country 68 - United Arab Emirates
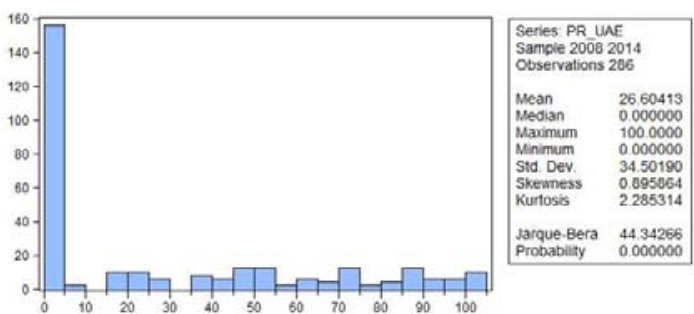

Country 70 - United States of America

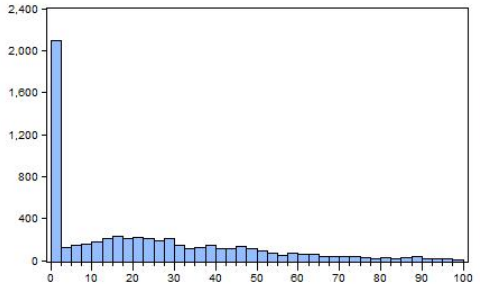

Series: PR USA 2008 2014 IF PR_USA 100

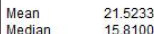

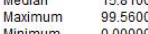
Std. Dev. $\quad 23.36711$

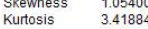
$\begin{array}{ll}\text { Jarque-Bera } & 1147.074 \\ \text { Probability } & 0.000000\end{array}$ 
Country $71-$ Venezuela

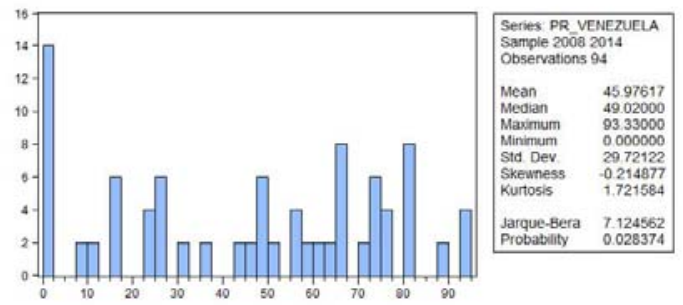

Country $73-$ Zimbabwe

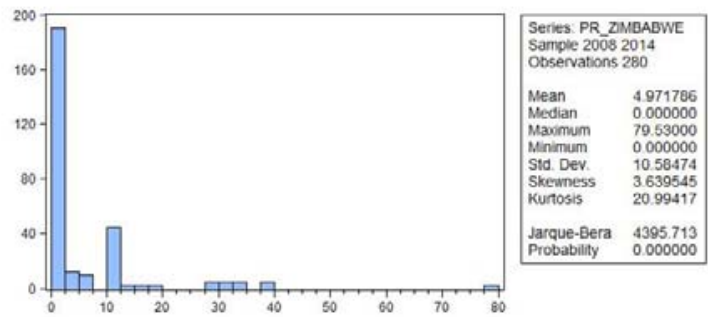

Country 72 - Zambia

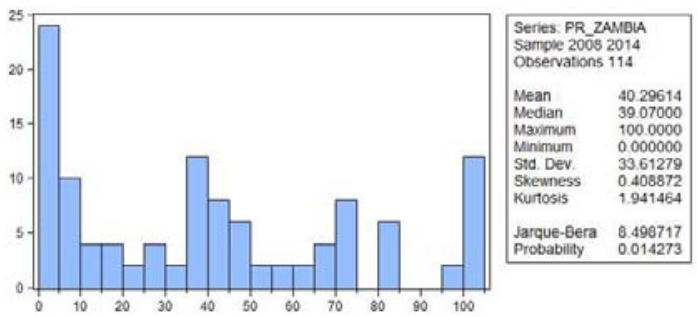

Appendix 2: Descriptive statistics

Table A.2.1: Descriptive statistics

\begin{tabular}{|c|c|c|c|c|c|c|c|}
\hline Indicator & & count & $\max$ & average & median & $\min$ & $\begin{array}{l}\text { Standard } \\
\text { deviation }\end{array}$ \\
\hline $\begin{array}{l}\text { Dividend Payout } \\
\text { Ratio }\end{array}$ & $\%$ & 71,814 & 100.00 & 27.74 & 21.84 & 0.00 & 28.38 \\
\hline
\end{tabular}

Source: own calculation based on database from Thomson Reuters Worldscope.

\section{Appendix 3: Countries with zero-inflated distributions versus countries with other distributions of Dividend payout ratio}

It can be noticed that zero-inflated distribution is not characteristic for all the countries included in our database (approximatively $26 \%$ from the total database are in this case) (see Table A.3.1). In some cases, this state is associated with a lower number of observations (e.g., Kazakhstan, Latvia, Luxembourg, Former Yugoslav Republic of Macedonia, Slovenia), but also the zeroinflated distribution appears in cases with a lower number of observations (e.g., Bulgaria, Czech Republic). In addition, it can be noticed that some developed countries, most of them from European Space (Belgium, Luxembourg, France, Germany, Spain, Sweden, Switzerland, UK), but, also, Japan are present in this category. 
Economics: The Open-Access, Open-Assessment E-Journal 13 (2019-45)

Table A.3.1: Countries with zero-inflated distributions versus countries with other distributions of Dividend payout ratio

\begin{tabular}{|c|c|}
\hline Zero-inflated distribution & Other distributions \\
\hline Austria & Belgium \\
\hline Argentina & Bulgaria \\
\hline Australia & Chile \\
\hline Bahrein & Cote d'Ivoire \\
\hline Bangladesh & Former Yugoslav Republic of Macedonia \\
\hline Brazil & France \\
\hline Bulgaria & Germany \\
\hline Canada & Hong-Kong \\
\hline China & Japan \\
\hline Croatia & Kazakhstan \\
\hline Czech Republic & Kenya \\
\hline Denmark & Latvia \\
\hline Egypt & Luxembourg \\
\hline Estonia & Mauritius \\
\hline Finland & Slovenia \\
\hline Greece & Spain \\
\hline Holland & Sweden \\
\hline Hungary & Switzerland \\
\hline India & United Kingdom \\
\hline \multicolumn{2}{|l|}{ Indonesia } \\
\hline \multicolumn{2}{|l|}{ Ireland } \\
\hline \multicolumn{2}{|l|}{ Israel } \\
\hline \multicolumn{2}{|l|}{ Italy } \\
\hline \multicolumn{2}{|l|}{ Kuwait } \\
\hline \multicolumn{2}{|l|}{ Lithuania } \\
\hline \multicolumn{2}{|l|}{ Malaysia } \\
\hline \multicolumn{2}{|l|}{ Malta } \\
\hline \multicolumn{2}{|l|}{ Mexico } \\
\hline \multicolumn{2}{|l|}{ Morocco } \\
\hline \multicolumn{2}{|l|}{ New Zeeland } \\
\hline \multicolumn{2}{|l|}{ Norway } \\
\hline \multicolumn{2}{|l|}{ Pakistan } \\
\hline \multicolumn{2}{|l|}{ Palestine } \\
\hline \multicolumn{2}{|l|}{ Peru } \\
\hline \multicolumn{2}{|l|}{ Philippines } \\
\hline \multicolumn{2}{|l|}{ Poland } \\
\hline \multicolumn{2}{|l|}{ Portugal } \\
\hline \multicolumn{2}{|l|}{ Romania } \\
\hline \multicolumn{2}{|l|}{ Russia } \\
\hline \multicolumn{2}{|l|}{ Saudi Arabia } \\
\hline Serbia & \\
\hline South Africa & \\
\hline South Korea & \\
\hline Sri Lanka & \\
\hline Thailand & \\
\hline Tunisia & \\
\hline Turkey & \\
\hline Ukraine & \\
\hline United Arad Emirates & \\
\hline United States of America & \\
\hline Venezuela & \\
\hline Zambia & \\
\hline Zimbabwe & \\
\hline
\end{tabular}

Note: the results for Oman are not conclusive. 
It can be suspected that the situation from Table A.3.1 can be related to the capital market development (see market capitalization as proxy). However, from the first 10 countries ranked function of market capitalization, ${ }^{15}$ four present a zero-inflated distribution (US, China, Canada, India). Considering the value of stocks traded as percent in GDP, ${ }^{16}$ six present a zero-inflated distribution. 17

One interesting future direction for analysis is to consider some cultural determinants for explaining this zero-inflated distribution for DPR. These similarities can be explained by similar cultural dimensions or people behaviour. For example, similar harmony index (Yaseen and Dragotă, 2019) or similar life standards (Yaseen, 2019) in those countries may lead to similar decisions regarding paying dividends or not.

\section{Appendix 4: Parameters of the Tweedie and Scaled Tweedie distribution, by country}

Table A.4.1: Estimated Parameters of the Tweedie and Scaled Tweedie distribution, by country

\begin{tabular}{|c|c|c|c|c|c|c|}
\hline Country & $\begin{array}{l}\text { Distribution of } \\
\text { DPR } \\
\text { 2014) }\end{array}$ & $\begin{array}{l}\text { Theta } \\
\theta\end{array}$ & $\begin{array}{l}\mathrm{P} \\
p\end{array}$ & $\begin{array}{l}\mathrm{Mu} \\
\mu\end{array}$ & $\begin{array}{l}\text { Phi } \\
\phi\end{array}$ & $\begin{array}{l}\text { Lambda } \\
\lambda\end{array}$ \\
\hline Côte d'Ivoire & Burr & & & & & \\
\hline Luxembourg & Burr & & & & & \\
\hline Latvia & Exp & & & & & \\
\hline South Africa & STweedie & 0.029 & 1.139 & & & 2.150 \\
\hline Argentina & STweedie & 0.204 & 1.478 & & & 0.727 \\
\hline Australia & STweedie & 0.052 & 1.143 & & & 1.376 \\
\hline Austria & STweedie & 0.022 & 1.063 & & & 1.009 \\
\hline Canada & STweedie & 0.148 & 1.344 & & & 1.031 \\
\hline Denmark & STweedie & 0.105 & 1.283 & & & 0.653 \\
\hline Egypt & STweedie & 0.094 & 1.214 & & & 1.094 \\
\hline Switzerland & STweedie & 0.004 & 1.038 & & & 3.542 \\
\hline Estonia & STweedie & 0.101 & 1.258 & & & 0.928 \\
\hline Germany & STweedie & 0.021 & 1.144 & & & 3.000 \\
\hline Ghana & STweedie & 0.059 & 1.297 & & & 3.124 \\
\hline Greece & STweedie & 0.083 & 1.248 & & & 1.213 \\
\hline Hong Kong & STweedie & 0.010 & 1.099 & & & 3.954 \\
\hline Indonesia & STweedie & 0.109 & 1.288 & & & 0.502 \\
\hline Italy & STweedie & 0.018 & 1.070 & & & 1.699 \\
\hline Kenya & STweedie & 0.034 & 1.140 & & & 2.586 \\
\hline
\end{tabular}

15 Top 10 countries, as market capitalization (2019), according to: https://www.indexmundi.com/facts/indicators/CM.MKT.LCAP.CD/rankings, is: 1. US. 2. China. 3. Japan. 4. HongKong. 5. France. 6. Canada. 7. UK. 8. Germany. 9. India. 10. Switzerland.

16 Top 10 countries, as value of stocks traded as percent in GDP (2019), according to: https://www.indexmundi.com/facts/indicators/CM.MKT.TRAD.GD.ZS/rankings, is: 1. Hong-Kong. 2. US. 3. China. 4. South Africa. 5. Switzerland. 6. South Korea. 7. Japan. 8. Finland. 9. Italy. 10. Iceland.

17 We did not include in our study Iceland because of lack of data. 
Economics: The Open-Access, Open-Assessment E-Journal 13 (2019-45)

\begin{tabular}{|c|c|c|c|c|c|c|}
\hline Country & $\begin{array}{l}\text { Distribution of } \\
\text { DPR (2008- } \\
2014)\end{array}$ & $\begin{array}{l}\text { Theta } \\
\theta\end{array}$ & $\begin{array}{l}\mathrm{P} \\
p\end{array}$ & $\begin{array}{l}\mathrm{Mu} \\
\mu\end{array}$ & $\begin{array}{l}\text { Phi } \\
\phi\end{array}$ & $\begin{array}{l}\text { Lambda } \\
\lambda\end{array}$ \\
\hline Malaysia & STweedie & 0.031 & 1.129 & & & 1.868 \\
\hline Malta & STweedie & 0.041 & 1.149 & & & 2.219 \\
\hline Mauritius & STweedie & 0.022 & 1.179 & & & 3.945 \\
\hline Mexico & STweedie & 0.142 & 1.404 & & & 1.156 \\
\hline Morocco & STweedie & 0.031 & 1.120 & & & 2.340 \\
\hline Norway & STweedie & 0.140 & 1.295 & & & 0.476 \\
\hline Oman & STweedie & 0.033 & 1.139 & & & 2.105 \\
\hline Palestine & STweedie & 0.071 & 1.269 & & & 2.697 \\
\hline Philippines & STweedie & 0.053 & 1.261 & & & 1.711 \\
\hline Poland & STweedie & 0.125 & 1.259 & & & 0.335 \\
\hline Portugal & STweedie & 0.145 & 1.282 & & & 0.660 \\
\hline Russian Federation & STweedie & 0.112 & 1.432 & & & 1.285 \\
\hline Saudi Arabia & STweedie & 0.080 & 1.172 & & & 0.984 \\
\hline Rep. of Korea & STweedie & 0.057 & 1.336 & & & 1.662 \\
\hline Spain & STweedie & 0.007 & 1.053 & & & 3.594 \\
\hline Sri Lanka & STweedie & 0.109 & 1.356 & & & 1.212 \\
\hline Sweden & STweedie & 0.003 & 1.027 & & & 4.111 \\
\hline Thailand & STweedie & 0.061 & 1.157 & & & 1.161 \\
\hline Ukraine & STweedie & 0.212 & 1.631 & & & 1.739 \\
\hline United Kingdom & STweedie & 0.021 & 1.144 & & & 3.525 \\
\hline United States & STweedie & 0.094 & 1.326 & & & 1.103 \\
\hline Venezuela & STweedie & 0.190 & 1.537 & & & 2.805 \\
\hline Bahrain & Tweedie & & 1.050 & 0.430 & 0.210 & \\
\hline Bangladesh & Tweedie & & 1.375 & 0.286 & 0.600 & \\
\hline Belgium & Tweedie & & 1.054 & 0.442 & 0.181 & \\
\hline Brazil & Tweedie & & 1.267 & 0.334 & 0.351 & \\
\hline Bulgaria & Tweedie & & 1.703 & 0.322 & 0.677 & \\
\hline Czech Republic & Tweedie & & 1.487 & 0.290 & 1.454 & \\
\hline Chile & Tweedie & & 1.181 & 0.417 & 0.238 & \\
\hline China & Tweedie & & 1.218 & 0.202 & 0.507 & \\
\hline Croatia & Tweedie & & 1.407 & 0.257 & 0.742 & \\
\hline Finland & Tweedie & & 1.144 & 0.413 & 0.394 & \\
\hline France & Tweedie & & 1.095 & 0.419 & 0.145 & \\
\hline Hungary & Tweedie & & 1.408 & 0.159 & 0.933 & \\
\hline India & Tweedie & & 1.268 & 0.233 & 0.191 & \\
\hline Ireland & Tweedie & & 1.160 & 0.168 & 0.411 & \\
\hline Israel & Tweedie & & 1.255 & 0.293 & 0.530 & \\
\hline Japan & Tweedie & & 1.124 & 0.305 & 0.133 & \\
\hline Kazakhstan & Tweedie & & 1.695 & 0.382 & 0.593 & \\
\hline Kuwait & Tweedie & & 1.083 & 0.318 & 0.492 & \\
\hline Lithuania & Tweedie & & 1.315 & 0.233 & 0.641 & \\
\hline
\end{tabular}


Economics: The Open-Access, Open-Assessment E-Journal 13 (2019-45)

\begin{tabular}{lllllll}
\hline Country & Distribution of & Theta & P & Mu & Phi & Lambda \\
& DPR (2008- $\theta$ & $p$ & $\mu$ & $\phi$ & $\lambda$ \\
& 2014) & & & & & \\
\hline FYR of Macedonia & Tweedie & & 2.639 & 0.390 & 0.534 & \\
Netherlands & Tweedie & & 1.097 & 0.381 & 0.203 & \\
New Zealand & Tweedie & 1.030 & 0.587 & 0.183 & \\
Pakistan & Tweedie & 1.234 & 0.395 & 0.356 & \\
Peru & Tweedie & 1.073 & 0.274 & 0.271 & \\
Romania & Tweedie & 1.186 & 0.280 & 0.607 & \\
Serbia & Tweedie & & 1.595 & 0.322 & 0.516 & \\
Slovenia & Tweedie & & 1.583 & 0.249 & 0.478 & \\
Tunisia & Tweedie & 1.136 & 0.389 & 0.379 & \\
Turkey & Tweedie & & 1.325 & 0.230 & 0.714 & \\
United Arab Emirates & Tweedie & & 1.193 & 0.266 & 0.708 & \\
Zambia & Tweedie & & 1.336 & 0.402 & 0.447 & \\
Zimbabwe & Tweedie & & 1.620 & 0.049 & 1.828 & \\
\hline
\end{tabular}




\section{Economics}

Please note:

You are most sincerely encouraged to participate in the open assessment of this article. You can do so by either recommending the article or by posting your comments.

Please go to:

http://dx.doi.org/10.5018/economics-ejournal.ja.2019-45

The Editor 